\title{
pH-Dependent Inhibition of Kainate Receptors by Zinc
}

\author{
David D. Mott, ${ }^{1}$ Morris Benveniste,${ }^{2}$ and Raymond J. Dingledine ${ }^{3}$ \\ ${ }^{1}$ Department of Pharmacology, Physiology, and Neuroscience, University of South Carolina School of Medicine, Columbia, South Carolina 29208, \\ ${ }^{2}$ Neuroscience Institute, Morehouse School of Medicine, Atlanta, Georgia 30310, and ${ }^{3}$ Department of Pharmacology, Emory University School of Medicine, \\ Atlanta, Georgia 30322
}

Kainate receptors contribute to synaptic plasticity and rhythmic oscillatory firing of neurons in corticolimbic circuits including hippocampal area CA3. We use zinc chelators and mice deficient in zinc transporters to show that synaptically released zinc inhibits postsynaptic kainate receptors at mossy fiber synapses and limits frequency facilitation of kainate, but not AMPA EPSCs during thetapattern stimulation. Exogenous zinc also inhibits the facilitatory modulation of mossy fiber axon excitability by kainate but does not suppress the depressive effect of kainate on CA3 axons. Recombinant kainate receptors are inhibited in a subunit-dependent manner by physiologically relevant concentrations of zinc, with receptors containing the KAl subunit being sensitive to submicromolar concentrations of zinc. Zinc inhibition does not alter receptor desensitization nor apparent agonist affinity and is only weakly voltage dependent, which points to an allosteric mechanism. Zinc inhibition is reduced at acidic $\mathrm{pH}$. Thus, in the presence of zinc, a fall in $\mathrm{pH}$ potentiates kainate receptors by relieving zinc inhibition. Acidification of the extracellular space, as occurs during repetitive activity, may therefore serve to unmask kainate receptor neurotransmission. We conclude that zinc modulation of kainate receptors serves an important role in shaping kainate neurotransmission in the $\mathrm{CA} 3$ region.

Key words: zinc; kainate receptor; CA3; glutamate receptor; mossy fiber; hippocampus; $\mathrm{pH}$

\section{Introduction}

Glutamate mediates fast synaptic transmission through NMDA, AMPA, and kainate receptors (Dingledine et al., 1999). Kainate receptor function has been studied at many synapses (Huettner, 2003; Lerma, 2003), but has been best characterized at synapses between mossy fibers (MFs) and CA3 pyramidal cells in the hippocampus (Castillo et al., 1997; Vignes and Collingridge, 1997). At mossy fiber synapses, postsynaptic kainate receptors produce excitatory currents (Castillo et al., 1997) and contribute to temporal summation of synaptic input (Frerking and OhligerFrerking, 2002). Presynaptic kainate receptors contribute to frequency facilitation (Schmitz et al., 2001) and long-term potentiation (Bortolotto et al., 1999). In addition, kainate receptors regulate excitability of mossy fiber axons (Kamiya and Ozawa, 2000; Schmitz et al., 2000). Low kainate concentrations enhance, whereas high concentrations depress mossy fiber excitability. Moreover, kainate receptors at these synapses contribute to seizure development (Mulle et al., 1998). The important role of kainate receptors in mossy fiber synaptic transmission suggests that endogenous agents that regulate kainate receptor function may modulate excitability of CA3 neurons.

In this study, we examined regulation of kainate receptor

Received Aug. 6, 2007; revised Jan. 1, 2008; accepted Jan. 5, 2008.

This work was supported by the Epilepsy Foundation (D.M.), National Alliance for Research on Schizophrenia and Depression (D.M.), the University Research Council of Emory University (D.M.), National Institute of Neurological Disorders and Stroke (R.D.), and the South Carolina Research Foundation (D.M.). We thank S. Misra, N. Ciliax, S. Zhang, and R. Shaw for excellent technical assistance.

Correspondence should be addressed to Dr. David D. Mott, Department of Pharmacology, Physiology, and Neuroscience, School of Medicine, University of South Carolina, Columbia, SC 29208. E-mail: dmott@med.sc.edu. DOI:10.1523/JNEUROSCI.3567-07.2008

Copyright $\odot 2008$ Society for Neuroscience $\quad$ 0270-6474/08/281659-13\$15.00/0 function by zinc. Zinc is concentrated in excitatory terminals throughout the brain and is particularly abundant in terminals of hippocampal mossy fibers (Frederickson and Danscher, 1990; Frederickson et al., 2000). In these terminals, zinc is colocalized with glutamate in synaptic vesicles. Zinc is released in a calciumdependent manner, after multiple (Assaf and Chung, 1984; Howell et al., 1984) or single (Quinta-Ferreira et al. 2004) mossy fiber stimuli, then taken up by zinc transport processes (Cole et al., 1999) and refilled into synaptic vesicles (Sudhof, 1995; Clemens, 1996). Previous estimates of the peak synaptic zinc concentration during neuronal activity are 10-30 $\mu \mathrm{M}$ (Thompson et al., 2000; Li et al., 2001b; Ueno et al., 2002) (but see Kay, 2003). Resting zinc concentration is in the low nanomolar range because of highaffinity binding of zinc to extracellular matrix proteins.

Endogenous zinc inhibits postsynaptic NMDA and $\mathrm{GABA}_{\mathrm{A}}$ receptors in hippocampus (Vogt et al., 2000; Ueno et al., 2002; Ruiz et al., 2004). NR2A containing NMDA receptors are most sensitive to zinc, being inhibited by low nanomolar concentrations (Chen et al., 1997; Paoletti et al., 1997). AMPA receptors are unaffected or even potentiated by physiologically relevant concentrations of zinc (Mayer et al., 1989; Dreixler and Leonard, 1994; Lin et al., 2001). At native kainate receptors the effects of zinc have not been studied, however zinc was reported to inhibit recombinant glutamate receptor 6 (GluR6) (Hoo et al., 1994) and GluR6/KA2 kainate receptors (Fukushima et al., 2003).

We found that endogenous zinc inhibits postsynaptic kainate receptors at mossy fiber synapses. This zinc inhibition limits frequency facilitation of kainate, but not AMPA receptors. Zinc inhibition of kainate receptors is subunit dependent with KA1 containing receptors being sensitive to submicromolar zinc concentrations. Furthermore, protons relieve zinc inhibition, pro- 
ducing an apparent potentiation of the response. Acidification of the extracellular space during strong activation of the synapse may therefore unmask kainate neurotransmission that is tonically inhibited by released zinc.

\section{Materials and Methods}

Preparation of hippocampal slices. Transverse brain slices were prepared from isoflurane-anesthetized male Sprague Dawley rats or mocha mutant mice using a vibratome (VT1000S; Leica, Nussloch, Germany). Brain slices were $300 \mu \mathrm{m}$ thick for whole-cell recording (16- to 27-d-old rats) and $500 \mu \mathrm{m}$ thick for field potential recording (21- to 45-d-old rats or adult mice). Brain slices were incubated in room temperature ACSF (artificial CSF) containing (in mM) $120 \mathrm{NaCl}, 3.3 \mathrm{KCl}, 1.0 \mathrm{NaH}_{2} \mathrm{PO}_{4}, 25$ $\mathrm{NaHCO}_{3}, 10$ glucose, $0.5 \mathrm{CaCl}_{2}$, and $5 \mathrm{MgCl}_{2}$ and bubbled with a $95 \%$ $\mathrm{O}_{2} / 5 \% \mathrm{CO}_{2}$ gas mixture at $\mathrm{pH}$ 7.4. Osmolarity was 301-308 mOsm.

Whole-cell recording. Slices were individually transferred to a recording chamber maintained at $32-34^{\circ} \mathrm{C}$ and continuously perfused with oxygenated ACSF, pH 7.4, containing $1.5 \mathrm{mM} \mathrm{CaCl}_{2}$ and $1.5 \mathrm{~mm} \mathrm{MgCl}_{2}$. For experiments at $\mathrm{pH}$ 6.7, the ACSF contained $5 \mathrm{~mm} \mathrm{NaHCO}_{3}$ and $140 \mathrm{~mm}$ $\mathrm{NaCl}$. Whole-cell recordings were obtained using borosilicate glass electrodes (3-10 M $\Omega$ ) filled with an internal solution containing (in mM) 130 Cs-gluconate, $5 \mathrm{CsCl}, 10 \mathrm{HEPES}, 0.5 \mathrm{CaCl}_{2}, 5 \mathrm{Cs}$-BAPTA, $2 \mathrm{MgCl}_{2}, 2$ MgATP, and 0.3 NaGTP, pH 7.3. Whole-cell patch-clamp recordings were made from pyramidal cells in the $\mathrm{CA} 3 \mathrm{~b}$ region of the hippocampus, visually identified with infrared-differential interference contrast optics. Voltage-clamp recordings were made at a holding potential of $-60 \mathrm{mV}$. Series resistance was $10-25 \mathrm{M} \Omega$, and recordings in which series resistance changed significantly were discarded.

Miniature synaptic currents were recorded in the presence of $1 \mu \mathrm{M}$ tetrodotoxin and $100 \mu \mathrm{M}$ each of CaEDTA, bicuculline methochloride, and D-APV. Where indicated, synaptic currents were evoked by a glass electrode filled with ACSF placed in stratum lucidum of CA3b. AMPA EPSCs were recorded as composite MF-EPSCs with ACSF containing 100 $\mu \mathrm{M}$ each bicuculline methochloride, D-APV, and CaEDTA. MF-evoked EPSCs were identified by their large paired-pulse facilitation $(>200 \%$ at a $50 \mathrm{~ms}$ interval) (Salin et al., 1996), rapid rise time, and short latency. These EPSCs were inhibited by the group II mGluR agonist $\left(2 S, 2^{\prime} R, 3^{\prime} R\right)$ 2-(2',3'-dicarboxycyclopropyl)glycine (DCG-IV; $1 \mu \mathrm{M})$, which was bath applied in each experiment. Kainate EPSCs were recorded from CA3 pyramidal cells in the presence of $100 \mu \mathrm{M}$ each of the AMPA antagonist 4-(8-methyl-9H-1,3-dioxolo[4,5-h][2,3]benzodiazepin-5yl)-benzenamine (GYKI 52466), CaEDTA, bicuculline methochloride, and D-APV. Small kainate EPSCs that were obscured by stimulation artifacts were resolved by the subtraction of a template stimulation trace that was acquired after application of CNQX $(100 \mu \mathrm{M})$ at the end of the recordings.

Responses were recorded using a Multiclamp 700A amplifier and filtered at $1 \mathrm{kHz}$. Responses were digitized by a Digidata 1320 analog-todigital (A-D) board (Molecular Devices, Sunnyvale, CA) in a Windowsbased computer using pClamp 9 software.

Field-potential recording. For recording, slices were placed into a small submersion chamber maintained at $32-34^{\circ} \mathrm{C}$ and held in place by a bent piece of platinum wire resting on the surface of the slice. Slices were perfused with ACSF containing $1.5 \mathrm{~mm} \mathrm{CaCl}_{2}$ and $1.5 \mathrm{~mm} \mathrm{MgCl}_{2}$.

Stimuli were $0.1 \mathrm{~ms}$, monophasic, cathodal, rectangular, constantcurrent pulses $(10-700 \mu \mathrm{A})$ delivered through a monopolar platinumiridium electrode referenced to a bath ground. Mossy fibers were stimulated either in the granule cell layer or in stratum lucidum of CA3c. Associational fibers were stimulated in stratum radiatum of CA3b. For extracellular recording, a glass pipette (resistance $5 \mathrm{M} \Omega$ ) filled with recording ACSF was placed in stratum lucidum of CA3b to record mossy fiber field EPSPs (fEPSPs) or in the granule cell layer to record mossy fiber antidromic spikes. Responses were recorded using an Axopatch 200 amplifier and filtered at $1 \mathrm{kHz}$. Responses were digitized by a Digidata 1200 A-D board (Molecular Devices) in a Windows-based computer using pClamp 9 software.

To examine the effect of zinc chelators, mossy fibers were stimulated using theta-pattern stimulation in which brief bursts of stimuli $(100 \mathrm{~Hz}$, five pulses) were delivered to the mossy fibers every $200 \mathrm{~ms}$ for $1 \mathrm{~s}$. This stimulation pattern was chosen as it simulates the discharge pattern of granule cells during behaviors associated with theta rhythm generation (Rose et al., 1983; Jung and McNaughton, 1993; Henze et al., 2002).

Oocyte preparation and injection. Xenopus oocytes were prepared and injected as described previously (Mott et al., 2003). Briefly, stage V-VI oocytes were isolated from anesthetized frogs, enzymatically treated by gentle shaking with collagenase (type IV; Worthington Biochemical, Lakewood, NJ; $1.7 \mathrm{mg} / \mathrm{ml}$ for 45-120 min) in a calcium-free Barth's solution and then (in some cases) manually defolliculated. Cells were injected with up to $50 \mathrm{ng}$ of mRNA transcribed from linearized constructs in either a pGEM-HE, pSGEM, or Bluescript (Stratagene, La Jolla, $\mathrm{CA}$ ) vector. For heteromeric receptors, mRNA was injected at either a 10:1 ratio (GluR2:GluR3), a 1:6 ratio (GluR6:KA1 and GluR6:KA2), a 1:3 ratio (GluR5:KA2; NR1:NR2), or a 1:1 ratio (GluR5Q:GluR6R). Injected oocytes were maintained at $17^{\circ} \mathrm{C}$ in Barth's solution containing gentamycin $(100 \mu \mathrm{g} / \mathrm{ml})$, penicillin $(10 \mathrm{U} / \mathrm{ml})$, and streptomycin $(10 \mu \mathrm{g} / \mathrm{ml})$ for 3-10 d, after which two electrode voltage-clamp recordings were made at room temperature $\left(23-25^{\circ} \mathrm{C}\right)$ from cells continually perfused in a standard frog Ringer's solution. This solution contained (in $\mathrm{mM}$ ) 90 $\mathrm{NaCl}, 1 \mathrm{KCl}, 15 \mathrm{HEPES}, 0.1 \mathrm{CaCl}_{2}$, and $0.4 \mathrm{MgCl}_{2}$. The contaminating zinc concentration in this solution was measured by mass spectrometry to be $77 \mathrm{~nm}$. Recording pipettes were filled with $3 \mathrm{M} \mathrm{CsCl}$ plus $0.4 \mathrm{M}$ EGTA, pH 7.5, to chelate $\mathrm{Ca}^{2+}$ and thereby minimize the activation of calcium-dependent chloride currents. GluR6/KA1, GluR6/KA2, and GluR5/KA2 receptors were activated with AMPA (30-300 $\mu \mathrm{M})$. AMPA selectively activates heteromeric kainate receptors containing GluR6 and KA1 or KA2 subunits, but not GluR6 homomeric receptors (Seeburg, 1993). GluR5Q/GluR6R receptors were activated with 5-iodowillardiine and homomeric GluR5 and GluR6 receptors were activated by domoate (3-10 $\mu \mathrm{M})$ or kainate $(30 \mu \mathrm{M})$. To reduce desensitization when kainate was used as the agonist, oocytes were pretreated with concanavalin-A $(0.3 \mathrm{mg} / \mathrm{ml}$ for $3 \mathrm{~min})$ and then washed for at least $10 \mathrm{~min}$ before use. NMDA receptors were activated using NMDA (100 $\mu \mathrm{M})$ and glycine (10 $\mu \mathrm{M})$, and AMPA receptors were activated with kainate $(300 \mu \mathrm{M})$. When NMDA receptors were studied, the $\mathrm{MgCl}_{2}$ in the Ringer's solution was replaced with $0.4 \mathrm{~mm} \mathrm{BaCl}_{2}$. Currents were elicited from a holding potential of $-70 \mathrm{mV}$ except where specified. Current signals were digitized at $1 \mathrm{kHz}$ using a Digidata 1200 analog-to-digital converter (Molecular Devices). Current-voltage curves during steady-state current responses were generated using voltage ramps from $-100 \mathrm{mV}$ to $+70 \mathrm{mV}$ over a period of $1.3 \mathrm{~s}$. Ramp currents were analyzed by subtracting the average of the leak current before and after agonist application from the current obtained in the presence of agonist. At least three ramps were recorded and averaged for each condition in each oocyte. To study the effect of $\mathrm{pH}$, oocytes were perfused with Ringer's solution at the desired $\mathrm{pH}$ for $30-60$ $\mathrm{s}$ or until a stable baseline had been reached before subsequent agonist application. Application of each of the agonists produced a stable, rapidly rising and nondesensitizing or weakly desensitizing current in the majority of oocytes. Oocytes in which the current was not stable or in which the baseline holding current drifted by $>10 \%$ were discarded.

Data analysis. Analysis was performed using pClamp (Molecular Devices), Origin (MicroCal, Northampton, MA) and Prism (GraphPad, San Diego, CA) software packages. Statistical comparisons were performed using the appropriate Student's $t$ test or ANOVA with post hoc tests. Values are given as mean $\pm \mathrm{SE}$. Concentration-inhibition relationships were fitted by nonlinear regression to a logistic equation of the form $I=$ $I_{\min }+\left(100-I_{\min }\right) /\left(1+\left([A] / \mathrm{IC}_{50}\right)^{n_{\mathrm{H}}}\right)$ where $I$ is the current at a given concentration of agonist $([A]), I_{\min }$ is the minimum current, $\mathrm{IC}_{50}$ is the antagonist concentration producing half-maximal inhibition of the current, and $n_{\mathrm{H}}$ is the Hill coefficient. For most experiments, $I_{\min }$ was set to 0 .

Miniature EPSCs (mEPSCs) were analyzed using MiniAnalysis 5.6 (SynaptoSoft, Decatur, GA). For each event, the rise time (10-90\%), amplitude, and decay time constants were calculated. The detection threshold was set $2 \mathrm{pA}$ above the baseline noise level (3-5 pA). In the absence of AMPA antagonists, miniature AMPA, kainate, and mixed events were distinguished based on their kinetics (Cossart et al., 2002). To do this, a 5 min window of data was obtained in each experimental condition in a single experiment. All events in this window were individ- 
ually fitted using the MiniAnalysis program. Mixed events were identified as those in which the decay was best fit by a double exponential function. The SD of the fit given by the MiniAnalysis program was used to determine whether one or two exponentials best fit the decays. Events best described by a single exponential decay constant were then separated based on their decay time constant as described by Cossart et al. (2002). All monoexponential decay times were plotted against rise times for a given experimental window. Using this graph, fast AMPA and slow kainate mEPSCs could be easily differentiated. The kinetic limit of the decay time to separate fast AMPA and slow kainate mEPSCs was $\sim 25 \mathrm{~ms}$.

The effect of zinc on cumulative charge transfer for kainate and AMPA receptor-mediated mEPSCs was determined by comparing the total area of the mEPSC current for 3 min windows of data obtained from control, zinc, and wash in each experiment. Igor Pro (WaveMetrics, Lake Oswego, OR) with a custom-written macro was used to measure baseline subtracted charge transfer in $1 \mathrm{~s}$ epochs during the $3 \mathrm{~min}$ window. These values were summed to yield cumulative charge transfer.

Buffered zinc solutions. For zinc concentration-response curves we used tricine to buffer zinc concentrations $\leq 1 \mu \mathrm{M}$. These solutions were prepared according to the methods of Zheng et al. (1998) using the empirically determined binding constant of $10^{-5} \mathrm{M}$ (Paoletti et al., 1997). At $\mathrm{pH} 7.5$, we added into $10 \mathrm{~mm}$ tricine (pKa 8.15) the following bulk concentrations of $\mathrm{ZnCl}_{2}: 0.16,1.6,16,47$, and $155 \mu \mathrm{M}$. The estimated concentrations of free zinc were calculated with WinMAXC (Patton et al., 2004) and BAD (Brooks and Storey, 1992) and were 1, 10, 100, 300, and $1000 \mathrm{~nm}$.

At alkaline $\mathrm{pH}$ levels $(>8.0)$, creation of zinc-hydroxide complexes decreases the availability of free zinc. Because of this, the most alkaline $\mathrm{pH}$ used in this study was $\mathrm{pH}$ 8.3. For experiments at this $\mathrm{pH}$, the zinc concentration was compensated by adding the following concentrations of zinc: $1.7,17,51,170$, and $1701 \mu \mathrm{M}$. The corresponding estimated concentrations of free zinc were calculated with WinMAXC to be 1,10 , 30,100 , and $1000 \mathrm{~nm}$. It is important to note that we observed increased inhibition by zinc at alkaline $\mathrm{pH}$ levels indicating that any loss of free zinc from solution would cause us to underestimate our effect.

For experiments in brain slices that investigated the effects of zinc, we added $100 \mu \mathrm{M}$ CaEDTA to the ACSF to chelate any contaminating zinc in our ACSF or any zinc tonically present in the brain slice. We assumed that zinc bound to CaEDTA in a 1:1 molar ratio and so increased the concentration of added zinc by $100 \mu \mathrm{M}$ to achieve the desired final zinc concentration.

Materials. Mocha mutant mice $\left(A P-3 \delta^{-/-}\right)$on a $\mathrm{C} 57 \mathrm{BL} / 6 \mathrm{~J} \times \mathrm{C} 3 \mathrm{H}$ background were a generous gift from Margit Burmeister at the University of Michigan (Ann Arbor, MI) (Kantheti et al., 1998). GluR6(Q) and GluR6(R) in pGEM-HE and the pSGEM vector were a generous gift from M. Mayer (National Institutes of Health, Bethesda, MD). GluR6(Q) in the JG3.6 vector was generously provided by S. Heinemann (Salk Institute, San Diego, CA), as were GluR5, KA1, and KA2 plasmids. NR1 and NR2 were generously provided by S. Nakanishi (Osaka Bioscience Institute, Suita, Osaka, Japan). Kainate, CaEDTA, and glycine were purchased from Sigma (St. Louis, MO). GYKI 52466, domoate, s-AMPA, D-APV, bicuculline methochloride, CNQX, TTX, DCG-IV, and NMDA were purchased from Tocris Bioscience (Ellisville, MO). 5-Nitrobenzothiazole coumarin (BTC-5N) was purchased from Invitrogen (Carlsbad, CA). To minimize the concentration of contaminating zinc in our solutions we used only ultrapure salts (Sigma). All drugs were bath applied in the perfusion medium. Drugs were washed on until a steady-state effect was observed before any measurements were taken. CNQX was first dissolved in dimethyl sulfoxide and then added to the ACSF. To insure that the addition of 2.5 or $10 \mathrm{~mm}$ CaEDTA to the ACSF did not affect the overall $\mathrm{Ca}^{2+}$ concentration in the ACSF, we measured the $\mathrm{Ca}^{2+}$ concentration in the ACSF after addition of CaEDTA using a calcium electrode. $\mathrm{CaCl}_{2}$ was then added until the desired $\mathrm{Ca}^{2+}$ concentration in the ACSF was achieved.

\section{Results}

\section{Zinc selectively inhibits synaptic kainate receptors}

In the presence of tetrodotoxin spontaneous mEPSCs can be recorded from CA3 pyramidal cells. Pharmacological blockade of
$\mathrm{GABA}_{\mathrm{A}}$ and NMDA receptors reveals three populations of events with distinct kinetics. The first of these populations had rapid rise and decay time constants (Fig. $1 A-C$ ) and average amplitude of $26 \pm 1.5 \mathrm{pA}$. The second population had a slower rise and decay time and smaller average amplitude $(15 \pm 0.9 \mathrm{pA})$. Finally the third population of events had biphasic kinetics that reflected a mix of the fast and slow events. Mixed mEPSCs had rise times similar to the first population (Fig. 1C) and two-component exponential decays with one component comparable with the rapid decay of the first population, and a second component similar to the slow decay of the second population (Fig. 1C). CNQX (100 $\mu \mathrm{M})$ blocked all of these events indicating that they were mediated by AMPA or kainate receptors. GYKI 52466, at a concentration selective for antagonism of AMPA receptors, blocked the fast events, indicating that they were AMPA receptor mediated. The slow events remaining in the presence of GYKI 52466 were substantially reduced by $(2 S, 4 R)$-4-methylglutamic acid (Sym 2081) (3 $\mu \mathrm{M})$ (data not shown), consistent with kainate receptor mediation.

We used these kainate and AMPA receptor-mediated mEPSCs to test the zinc sensitivity of native synaptic kainate and AMPA receptors. Zinc $(100 \mu \mathrm{M})$ abolished the slow kainate mediated currents, preserving the population of fast AMPA receptor-mediated mEPSCs (Fig. $1 D$ ). We quantified the inhibitory effect of zinc on the kainate mEPSCs by pharmacologically isolating kainate mEPSCs with GYKI $52466(100 \mu \mathrm{M})$ and measuring the cumulative charge transfer attributable to kainate mEPSCs during a 3 min window (Fig. 2). Zinc produced a $94 \%$ decrease in the cumulative charge transfer of miniature kainate EPSCs (Fig. 2 B). CNQX (100 $\mu \mathrm{M}$ ) blocked all charge transfer. In the absence of GYKI 52466 but in the presence of Sym 2081, zinc had no effect on cumulative charge transfer (Fig. 2C). Under these conditions, AMPA receptor-mediated mEPSCs dominate. CNQX again blocked all charge transfer. Zinc had no effect on the frequency of AMPA mEPSCs nor did zinc change the amplitude distribution of AMPA mEPSCs (Fig. $2 D, E$ ), suggesting that zinc did not act presynaptically to alter glutamate release. These results suggest that $100 \mu \mathrm{M}$ zinc selectively blocks postsynaptic kainate receptors on $\mathrm{CA} 3$ pyramidal cells.

\section{Zinc inhibits mossy-fiber-evoked kainate responses}

The ability of endogenous zinc to inhibit evoked kainate responses in area CA3 was assessed using field potential recording. Mossy fiber- or commissural/associational (C/A)-evoked fEPSPs were studied in the presence of the NMDA receptor antagonist $\mathrm{D}-\mathrm{APV}(100 \mu \mathrm{M})$ and the $\mathrm{GABA}_{\mathrm{A}}$ receptor antagonist bicuculline $(100 \mu \mathrm{M})$. Mossy fibers were activated by stimulation in the dentate granule cell layer whereas commissural/associational fibers were stimulated in CA3 stratum radiatum (Fig. 3A). Mossy fiberevoked fEPSPs arise predominantly $(>90 \%)$ from activation of AMPA receptors with a small kainate receptor component (Contractor et al., 2003). This kainate component could be isolated by the addition of $100 \mu \mathrm{M}$ GYKI 52466 to our antagonist mixture. In the presence of these antagonists, theta-pattern stimulation (five pulses at $100 \mathrm{~Hz}$ every $200 \mathrm{~ms}$ for $1 \mathrm{~s}$ ) to the mossy fibers evoked a kainate receptor-mediated fEPSP that became progressively larger in successive bursts of the train (Fig. $3 A$, bottom right). In contrast, similar stimulation to the commissural/associational pathway evoked no response (Fig. $3 A$, bottom left). A $76 \pm 5 \%$ suppression of the mossy-fiber-evoked fEPSP by $1 \mu \mathrm{M}$ DCG-IV $(p<0.01 ; n=11)$ confirms specific mossy fiber activation (Fig. 3B) (Kamiya et al., 1996). This suppression was reversed by the group II mGluR antagonist (2S)-2-amino-2-[(1S,2S)-2-carboxy- 
cycloprop-1-yl]-3-(xanth-9-yl) propanoic acid (LY341495) (3 $\mu \mathrm{M})$. C/A-evoked responses were unaffected by DCG-IV ( $5 \pm$ $10 \% ; n=4)$ (Fig. 3B).

CNQX blocks AMPA receptors with higher affinity $\left(\mathrm{IC}_{50}, 0.4 \mu \mathrm{M}\right)$ than kainate receptors [at GluR6, $\mathrm{IC}_{50}=4 \mu \mathrm{M}$ (Fletcher and Lodge, 1996); at GluR6/KA2, $\mathrm{IC}_{50}=$ $78 \mu \mathrm{M}$ (Alt et al., 2004)]. AMPA fEPSPs evoked by MF stimulation were $71 \pm 7 \%$ $(n=4)$ suppressed by $1.5 \mu \mathrm{M}$ CNQX and $85 \pm 5 \%(n=3)$ suppressed by $100 \mu \mathrm{M}$ CNQX (Fig. 3C). In contrast, kainate receptor-mediated fEPSPs were not affected by $1.5 \mu \mathrm{M}$ CNQX $(n=3)$, but were $92 \pm 5 \%$ suppressed by $100 \mu \mathrm{M}$ CNQX $(n=3)$, further supporting the conclusion that these responses were produced by kainate receptors (Fig. 3C). The high concentration $(100 \mu \mathrm{M})$ of CNQX required to block kainate responses in these experiments is consistent with a contribution of GluR6/KA2 receptors to the synaptic response (Alt et al., 2004).

We tested the ability of exogenous zinc to inhibit these fEPSPs in hippocampal slices from 21- to 27-d-old rats. Kainate fEPSPs were evoked by MF stimulation $(100 \mathrm{~Hz}$, six pulses). Zinc $(30 \mu \mathrm{M})$ reversibly inhibited the kainate fEPSP by $59 \pm$ $8 \%(p<0.01 ; n=5)$ (Fig. 3D,F). Thirty micromolars zinc had no effect on AMPA fEPSPs elicited by single stimuli delivered to the mossy fibers in the presence of bicuculline methochloride and D-APV (Fig. $3 F)$. Zinc inhibition was quantified by measuring EPSC peak amplitudes from whole-cell recordings of CA3 pyramidal cells in the presence of GYKI 52466, $\mathrm{D}-\mathrm{APV}$, bicuculline, and different concentrations of zinc (16- to 17-d-old rats) (Fig. $3 E, G)$. The $\mathrm{IC}_{50}$ for zinc inhibition of kainate receptor-mediated EPSCs was $15 \pm 2$ $\mu \mathrm{M}$. In the absence of GYKI 52466, single stimuli to the mossy fibers evoked AMPA EPSCs. These EPSCs were not inhibited by $100 \mu \mathrm{M}$ zinc, indicating that at the concentrations tested zinc selectively inhibited synaptic kainate receptors.

\section{Endogenous zinc limits frequency facilitation of mossy-fiber-evoked kainate responses}

Zinc release is activity dependent (Frederickson et al., 2006a,b). Endogenously released zinc inhibits synaptic NMDA receptor currents (Vogt et al., 2000; Ueno et al., 2002) and regulates synaptic plasticity (Li et al., 2001a; Izumi et al., 2006). We used zinc chelators to test whether endogenously released zinc regulates kainate receptor-mediated fEPSPs at mossy fiber synapses. Zinc in mossy fiber boutons appears approximately synchronously with the developmental appearance of granule neurons (Frederickson et al., 2006a). According to Frederickson et al. (2006a), young rat pups (16 d old) have little
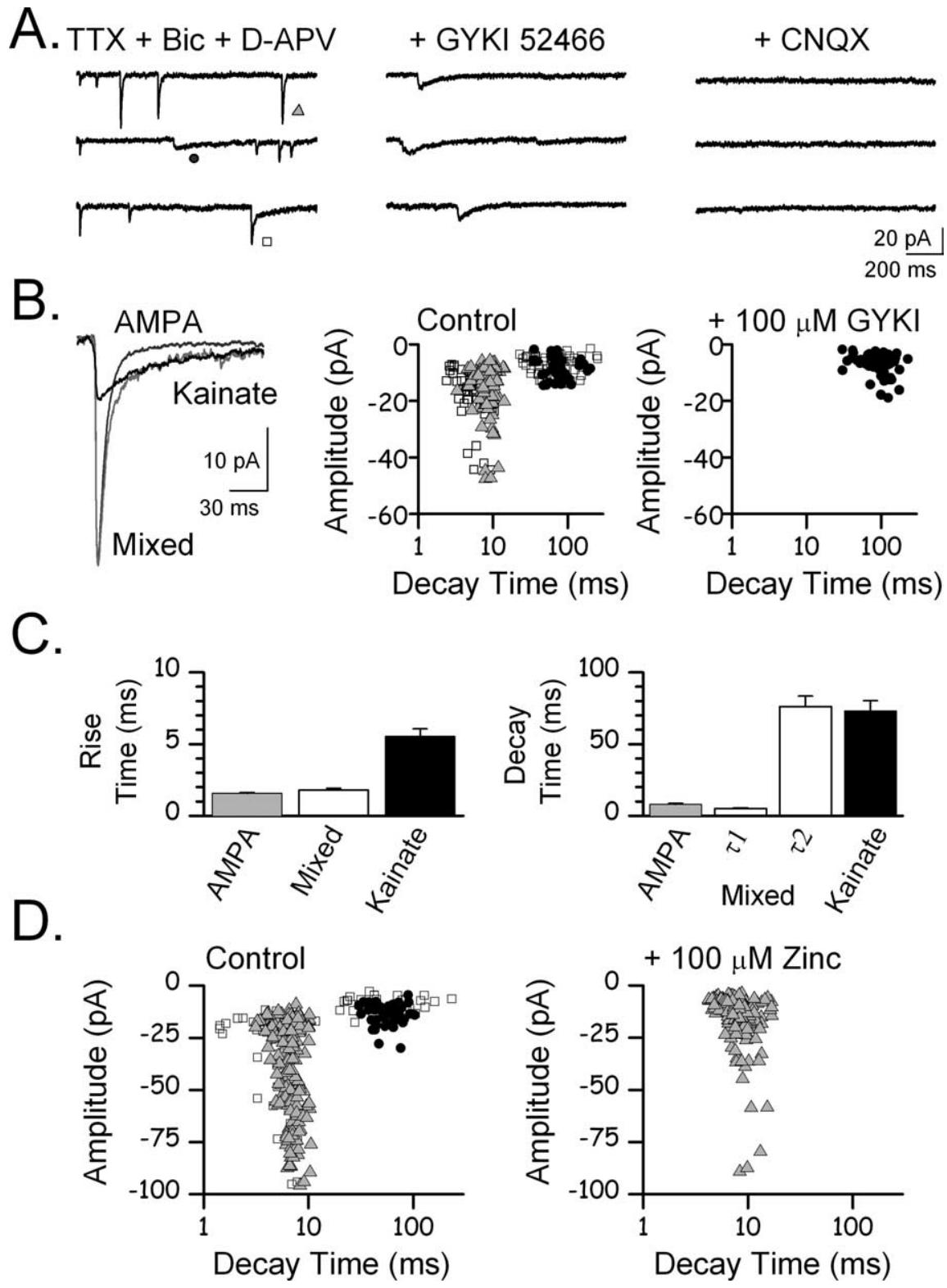

Figure 1. Spontaneous miniature EPSCs mediated by kainate but not AMPA receptors are inhibited by zinc. $\boldsymbol{A}$, Left, Spontaneous miniature currents mediated by AMPA and kainate receptors were recorded from a CA3 pyramidal cell in the presence of tetrodotoxin $(1 \mu \mathrm{M})$, bicuculline methochloride (100 $\mu \mathrm{m})$, and D-APV (100 $\mu \mathrm{m})$. Currents with fast (triangle), slow (circle), and mixed (square) kinetics were apparent. Middle, GYKI $52466(100 \mu \mathrm{m})$ at a concentration selective for AMPA receptors blocked the fast and mixed currents leaving only the currents with slow kinetics. Right, CNQX (100 $\mu \mathrm{m})$ blocked these slow currents, indicating that they were kainate receptor mediated. $\boldsymbol{B}$, Left, Superimposition of representative currents with fast, slow, and mixed kinetics. Currents with mixed kinetics decayed with a combination of fast and slow kinetics. Middle, Scatterplot of current amplitude versus decay time showing the separation of currents with fast (triangle), slow (circle), and mixed (square) kinetics into distinct groups. Right, GYKI 52466 blocked the currents with fast kinetics, leaving only the slower kainate currents. C, Average rise and decay times for currents mediated by AMPA and kainate receptors. Mixed current kinetics reflect a combination of both AMPA and kainate receptor current kinetics. D, Spontaneous $m E$ EPSCs with fast (triangle), slow (circle), and mixed (square) kinetics are present. Zinc blocks the slow kainate receptor-mediated mEPSCs, leaving only the fast AMPA mEPSCs.

synaptic zinc. As granule neurons develop and mossy fiber axons mature, increasing levels of zinc can be detected. By $23 \mathrm{~d}$ of age, zinc levels in the dentate hilus are $40-60 \%$ of adult levels and by 30 -d-old zinc levels have risen to $70-90 \%$ of adult levels. Therefore, to examine the effect of zinc chelators on kainate fEPSPs, we used 30- to 45-d-old rats.

Kainate receptors were pharmacologically isolated and thetapattern stimulus trains were delivered to the mossy fibers to evoke kainate receptor-mediated fEPSPs (Fig. 4A). The ampli- 


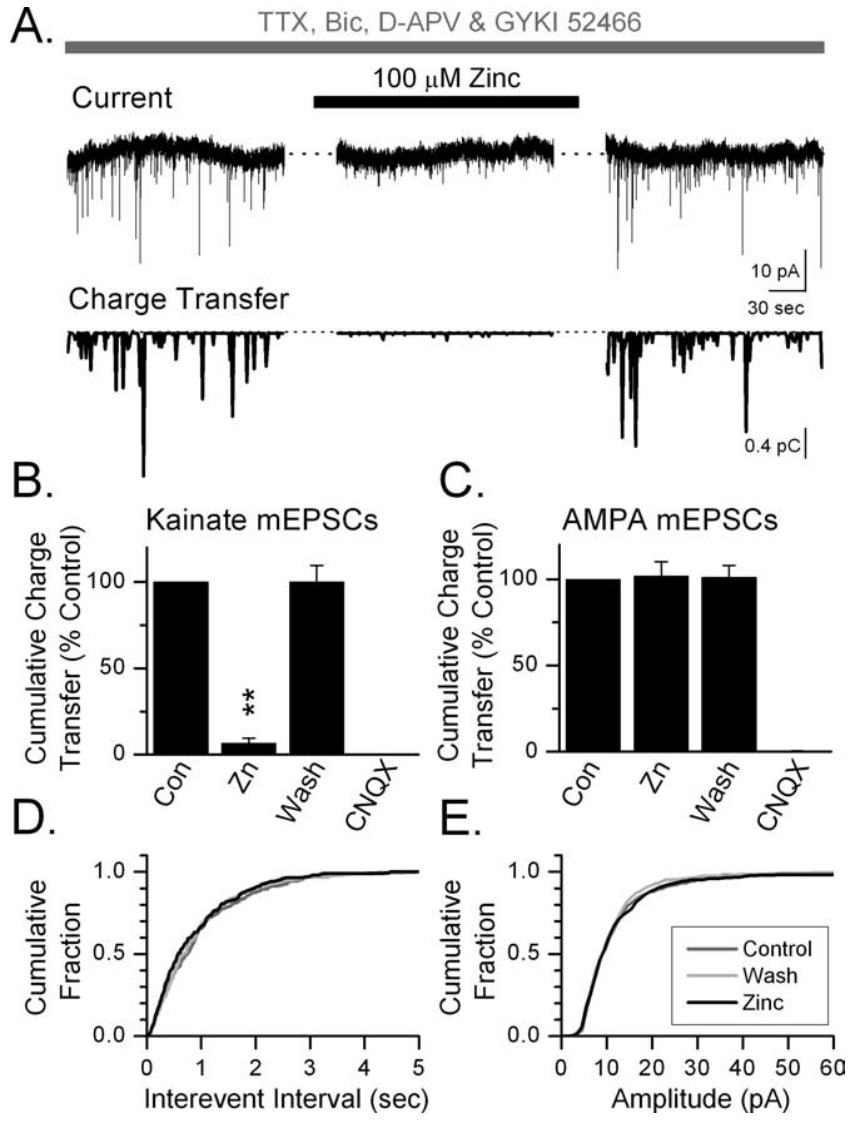

Figure2. Zincblocks postsynaptic kainate but not AMPA receptor-mediated mEPSCs. A, Top Current trace showing 3 min of spontaneous kainate receptor-mediated mEPSCS recorded in the presence of tetrodotoxin $(1 \mu \mathrm{M})$, bicuculline methochloride (Bic; $100 \mu \mathrm{M}), \mathrm{D}-\mathrm{APV}(100 \mu \mathrm{m})$, and GYKI $52466(100 \mu \mathrm{M})$. Downward deflections represent kainate receptor-mediated mEPSCs. Zinc reversibly blocks these kainate mEPSCs. Bottom, Instantaneous charge transfer measured in $1 \mathrm{~s}$ epochs during the $3 \mathrm{~min}$ current trace shown above. Zinc reversibly blocked this charge transfer. $\boldsymbol{B}$, By summing the charge transfer in each $1 \mathrm{~s}$ epoch, we determined the cumulative charge transfer. The cumulative charge transfer in each condition in each cell was calculated as a percentage of the cumulative charge transfer in control. Zinc (Zn; $100 \mu \mathrm{M})$ significantly and reversibly blocked this charge transfer $\left({ }^{* *} p<0.01 ; n=5\right)$. CNQX (100 $\left.\mu \mathrm{M}\right)$ completely blocked the mEPSCS $(p<0.01 ; n=5)$. C, Cumulative charge transfer attributable to spontaneous AMPA receptor-mediated mEPSCs was calculated in the presence of tetrodotoxin $(1 \mu \mathrm{M})$, bicuculline methochloride $(100 \mu \mathrm{M}), \mathrm{D}-\mathrm{APV}(100 \mu \mathrm{M})$, and Sym $2081(10 \mu \mathrm{M})$.Zinc $(100 \mu \mathrm{M})$ did not reduce the cumulative charge transfer, whereas $\operatorname{CNQX}(100 \mu \mathrm{m})$ blocked it $\left.{ }^{* *} p<0.01 ; n=4\right)$. The ability of zinc to reduce kainate, but not AMPA mEPSCs, suggests that zinc acts postsynaptically on kainate receptors. $\boldsymbol{D}, \boldsymbol{E}$, Cumulative probability plots showing that zinc caused no change in the frequency $(\boldsymbol{D})$ or amplitude distribution $(\boldsymbol{E})$ of AMPA receptor-mediated mEPSCS. These results further support a postsynaptic site for the action of zinc. Con, Control.

tude of the fEPSP evoked by the last burst of the train was measured. The average response time course of these kainate receptor-mediated responses from four experiments is shown in Figure $4 B$. In these experiments, application of the low-affinity zinc chelator BTC-5N $(100 \mu \mathrm{M})$ significantly $(p<0.05 ; n=4)$ enhanced the amplitude of the kainate receptor-mediated fEPSP in a reversible manner. Subsequent application of the highaffinity zinc chelator CaEDTA $(2.5 \mathrm{~mm})$ mildly potentiated the fEPSP $(112 \pm 6 \% ; n=4)$. Increasing the concentration of CaEDTA to $10 \mathrm{~mm}$ increased the potentiation $(140 \pm 17 \% ; n=4)$. These fEPSPs were produced by mossy fiber stimulation as they were $80 \pm 12 \%$ inhibited by $1 \mu \mathrm{M}$ DCG-IV $(n=4)$. These responses were $100 \pm 2 \%$ blocked by $100 \mu \mathrm{M} \operatorname{CNQX}(n=4)$ indicating that they were specifically mediated by kainate receptors because AMPA receptors had already been blocked by GYKI
52466. Overall, in hippocampal slices from a larger group of animals we found that both CaEDTA (10 mM; $134 \pm 11 \%$; $p<0.05$; $n=7)$ and BTC-5N (100 $\mu \mathrm{M} ; 145 \pm 15 \% ; p<0.01 ; n=8)$ significantly potentiated kainate fEPSPs. In contrast, BTC-5N had no effect on the amplitude of the AMPA receptor-mediated fEPSP evoked by a $5 \mathrm{~Hz}$ stimulus train delivered to the mossy fibers $(106 \pm 6 \% ; n=3)$. These results suggest that endogenous zinc inhibits kainate, but not AMPA receptors at mossy fiber synapses.

Theta-pattern stimulus trains to the mossy fibers produced strong frequency facilitation of both the mossy-fiber-evoked fEPSP (data not shown) and its isolated kainate receptor fEPSP component between the first and fifth stimulus trains (356 \pm $40 \% ; n=8)$ (Fig. $4 C)$. BTC-5N $(100 \mu \mathrm{M})$ significantly enhanced this frequency facilitation to $497 \pm 73 \%(n=8)$ (Fig. $4 A, C)$. Figure $4 \mathrm{C}$ indicates that the chelator had little effect on the kainate fEPSP during the first burst of the train, but produced a significantly greater potentiation on the fifth burst $(p<0.01)$. Comparison of the amplitude of each burst during the train in BTC- $5 \mathrm{~N}$ to the corresponding burst in control revealed a significant facilitation only after the second burst of the train (Fig. 4D). In contrast, during $5 \mathrm{~Hz}$ single pulse stimulation, the mossy fiberevoked AMPA fEPSP exhibited frequency facilitation, but this facilitation was not affected by BTC-5N (Fig. 4D). Because the effect of zinc chelation by BTC- $5 \mathrm{~N}$ increases with each stimulus burst, these results suggest that zinc is released and accumulates in the synaptic cleft during the stimulus trains, limiting frequency facilitation of kainate, but not AMPA receptor-mediated fEPSPs.

To further examine the role of endogenous zinc, we used mocha mutant mice. These mice express a natural mutation that results in loss of the ZnT3 zinc transporter from synaptic vesicles and so the mossy fibers fail to accumulate zinc. Other zinc stores are unchanged (Kantheti et al., 1998; Vogt et al., 2000). Using these mice we tested the ability of the zinc chelator, BTC-5N to facilitate the kainate receptor-mediated fEPSP during a thetapattern stimulus train to the mossy fibers. During the train the mossy-fiber-evoked kainate receptor-mediated fEPSP was facilitated $472 \pm 50 \%(n=4)$ (Fig. $4 E)$. However, in these animals, BTC-5N did not further facilitate the pharmacologically isolated kainate receptor-mediated fEPSP in the mossy fiber pathway, nor did it alter frequency facilitation of the kainate fEPSP (Fig. $4 E-$ $G)$. Activation of the mossy fibers in these experiments was confirmed by the sensitivity of the fEPSP to blockade by DCG-IV (70 $\pm 8 \%$ inhibition; $n=4 ; p<0.01$ ), and its reversal by LY341495. We confirmed that the response was generated by kainate receptor activation by demonstrating that it was inhibited by $100 \mu \mathrm{M}(91 \pm 4 \%$ inhibition; $n=4 ; p<0.01)$, but not $1.5 \mu \mathrm{M}$ CNQX $(9 \pm 6 \%$ inhibition; $n=4)$. The inability of BTC-5N to enhance kainate responses in mocha mutant mice further suggests that endogenously released zinc can inhibit postsynaptic kainate receptors.

\section{Zinc suppresses the facilitatory but not inhibitory effect of kainate on axon excitability}

Low nanomolar concentrations of kainate facilitate, whereas higher concentrations of kainate suppress, the excitability of mossy fiber axons (Kamiya and Ozawa, 2000; Schmitz et al., 2000 ). Both ambient as well as synaptically released glutamate in the extracellular space could activate these kainate receptors altering axonal excitability (Schmitz et al., 2000; Contractor et al., 2003). Kainate receptor modulation of axonal excitability would affect neuronal transmission and synaptic plasticity at mossy fibers. Zinc could therefore affect the fidelity of network transmis- 
sion by inhibiting axonal kainate receptors. To examine this issue, we tested the effect of zinc on the action of a low concentration of kainate at mossy fibers.

Granule cell axons were stimulated in CA3 stratum lucidum and the antidromic population spike recorded in the dentate gyrus granule cell layer. Kainate receptors were pharmacologically isolated by application of $100 \mu \mathrm{M}$ each of GYKI 52466, D-APV, and bicuculline methochloride. Kainate (500 nM) increased the amplitude of the antidromic spike by $31 \pm 6 \%(n=6$, $p<0.01)$. This increase in spike amplitude was accompanied by a decrease in the latency of the spike, an increase in its rising slope and a decrease in its half width, indicating that kainate increased the synchrony of firing of mossy fibers (Fig. $5 A-C$ ). Because peak amplitude of the spike is affected by firing synchrony, we assessed the effect of kainate on the area of the antidromic spike. Kainate significantly increased the area of the MF antidromic spike $(p<0.01 ; n=5)$ (Fig. $5 D)$. One hundred micromolars zinc blocked kainate induced potentiation in a reversible manner $(p<0.01 ; n=5)$ (Fig. 5D). The averaged time course of the effect of kainate and zinc on the MF-evoked antidromic spike from four experiments is shown in Figure 5E. One hundred micromolars zinc completely reversed kainateevoked potentiation of the antidromic spike but did not depress the antidromic spike below baseline level. Washout of zinc was accelerated by addition of $400 \mu \mathrm{M}$ CaEDTA (total CaEDTA, $500 \mu \mathrm{M}$ ). One hundred micromolars CNQX blocked kainate-induced potentiation of the antidromic spike. When applied in the absence of kainate, $100 \mu \mathrm{M}$ zinc had no significant effect on the MF antidromic spike area $(97 \pm 5 \% ; n=5)$. These observations indicate that kainate receptors on mossy fiber axons are sensitive to zinc.

We compared the zinc sensitivity of kainate receptors on MF axons with that of kainate receptors on CA3 axons. Strong activation of kainate receptors on CA3 axons depresses fiber volleys recorded in area CA1 (Frerking et al., 2001). In contrast, weak activation of kainate receptors with nanomolar concentrations (200 nM) of domoate does not alter the amplitude of this fiber volley (Frerking et al., 2001). We stimulated CA3 axons in CA3 stratum radiatum and recorded the antidromic spike in the pyramidal cell layer. Kainate receptors were pharmacologically isolated as described above. In contrast to the lack of effect of $200 \mathrm{~nm}$ domoate on CA3 fiber volleys previously reported (Frerking et al., 2001), we found that low nanomolar concentrations of kainate $(20-500 \mathrm{~nm})$ strongly depressed CA3 antidromic spike area by decreasing the rising slope of the antidromic spike and increasing the half width. effect on the AMPA EPSC.

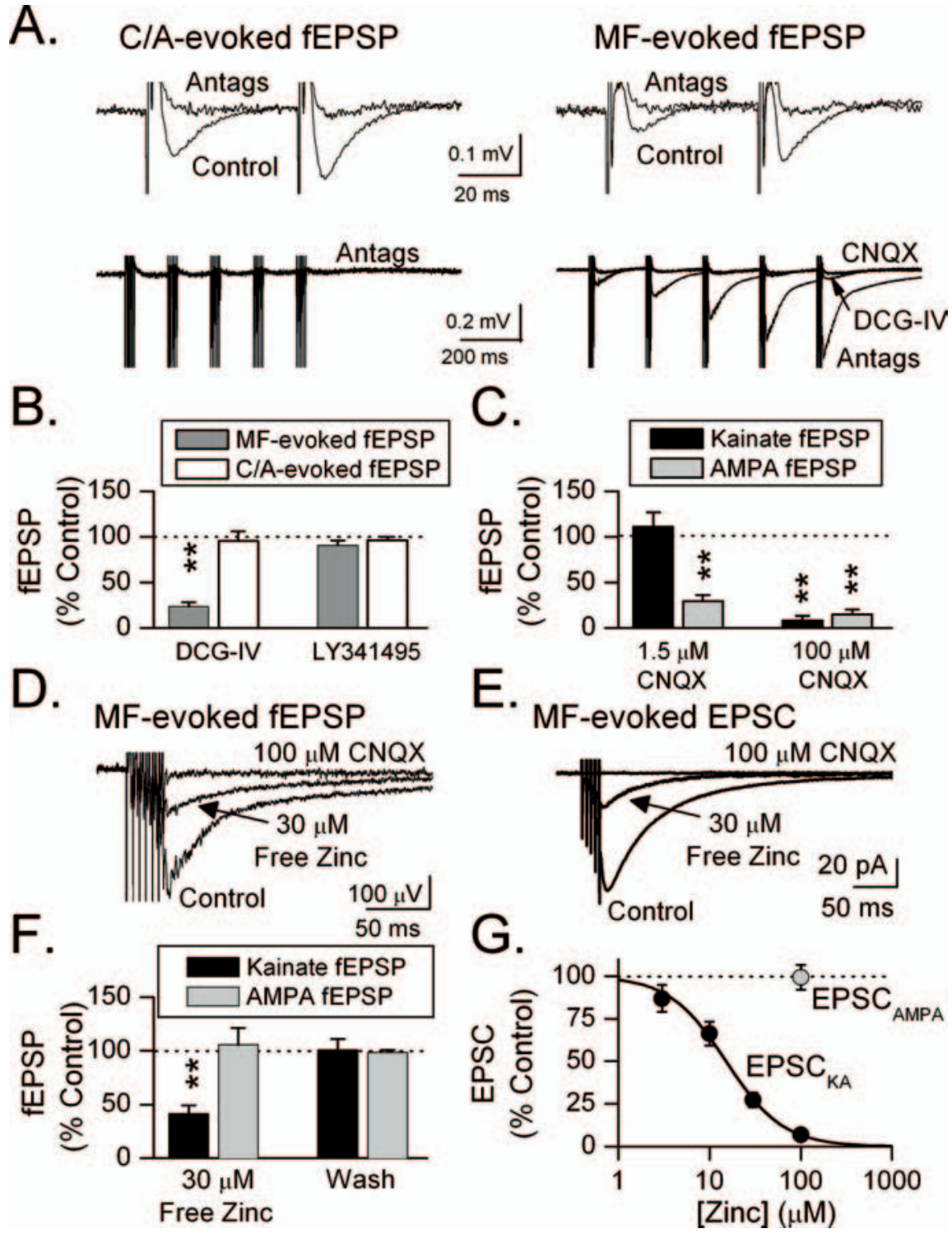

Figure 3. Zinc blocks kainate responses evoked by mossy fiber stimulation. $\boldsymbol{A}$, Paired stimulation to C/A- (left) or MF-evoked (right) fEPSPs (control). Application of a mixture of antagonists (Antags; $100 \mu \mathrm{m}$ each of bicuculline methochloride, D-APV, CaEDTA, and GYKI 52466) designed to isolate the kainate fEPSP blocked the fEPSPs. Theta-pattern stimulation (bottom traces; 100 $\mathrm{Hz}, 5$ pulses every $200 \mathrm{~ms}$ for $1 \mathrm{~s}$ ) restored the fEPSP in the MF but not C/A pathway. DCG-IV $(1 \mu \mathrm{m})$ suppressed this fEPSP, indicating that it was produced by MF stimulation. CNQX (100 $\mu \mathrm{m})$ blocked the response, indicating that it was kainate receptormediated. $B, D C G-I V(1 \mu \mathrm{M})$ significantly reduced the MF- $\left({ }^{* *} p<0.01 ; n=11\right)$, but not $C / A$-evoked $(n=4)$ fEPSP. The group II mGluR antagonist LY341495 (3 $\mu \mathrm{m})$ reversed the effect of DCG-IV. C, A low concentration of CNQX (1.5 $\mu \mathrm{m})$ suppressed the MF-evoked AMPA $(n=4)$, but not kainate fEPSP $(n=3)$, whereas a high concentration of CNQX (100 $\mu \mathrm{m})$ blocked both fEPSPs $\left({ }^{* *} p<0.01\right) . \boldsymbol{D}, \boldsymbol{E}$, In the antagonist mixture, a brief MF train $(100 \mathrm{~Hz})$ evoked a pharmacologically isolated kainate fEPSP $(\boldsymbol{D})$ or EPSC recorded in whole-cell mode $(\boldsymbol{E})$. Addition of $30 \mu \mathrm{m}$ free zinc (130 $\mu \mathrm{m}$ total zinc added to ACSF that contained $100 \mu \mathrm{m}$ CaEDTA) suppressed the kainate response. CNQX (100 $\mu \mathrm{m})$ blocked the response, indicating that it was kainate receptormediated. $\boldsymbol{F}$, The bar graph shows the selective inhibition of the kainate ( $p<0.05 ; n=5)$, but not AMPA $(n=5)$ fEPSP by 30 $\mu \mathrm{m}$ free zinc. $\mathbf{G}$, Zinc inhibited the MF-evoked kainate EPSC with an $\mathrm{IC}_{50}$ of $15 \pm 2 \mu \mathrm{M}(n=11)$. In contrast, $100 \mu \mathrm{m}$ zinc had no

Kainate depressed the CA3 antidromic spike area with an $\mathrm{IC}_{50}$ of $84 \pm 20 \mathrm{~nm}(n=7)$ (Fig. $5 H)$. This indicates that low concentrations of kainate may desynchronize action potential firing from CA3 pyramidal cells (Fig. $5 F, H$ ). This effect of low concentrations of kainate is in stark contrast to the facilitation of mossy fibers produced by similar concentrations of kainate. Indeed, in several experiments we observed opposite effects of $50 \mathrm{~nm}$ kainate at CA3 antidromic spikes and mossy fiber volleys recorded at the same location in the CA3 cell body layer. A moderate (50 nM) 
A.

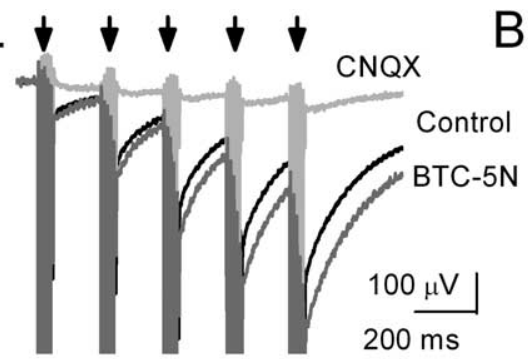

C.

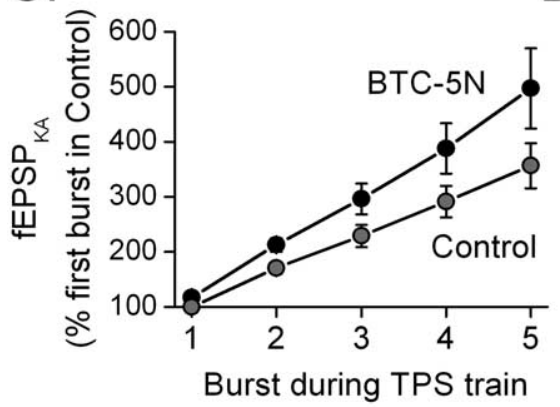

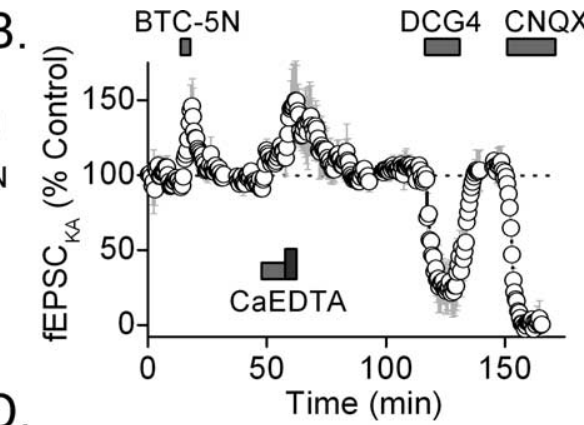

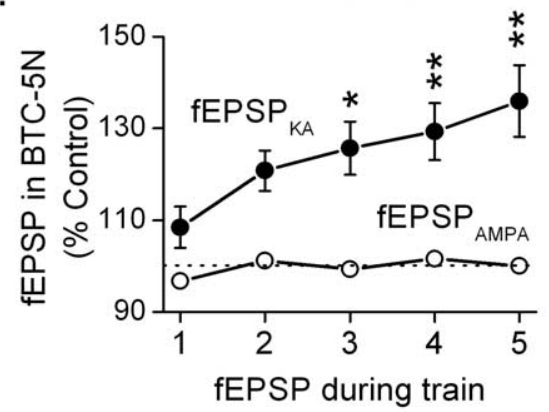

E.

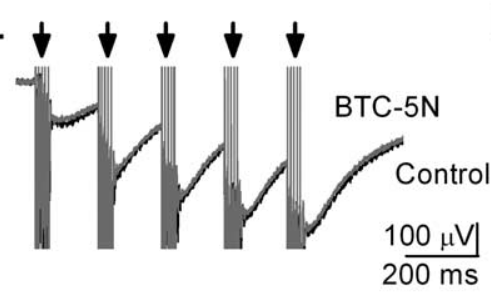

G.

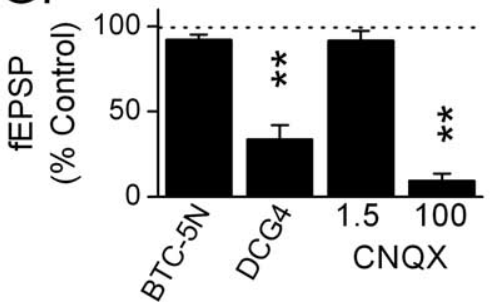

F.

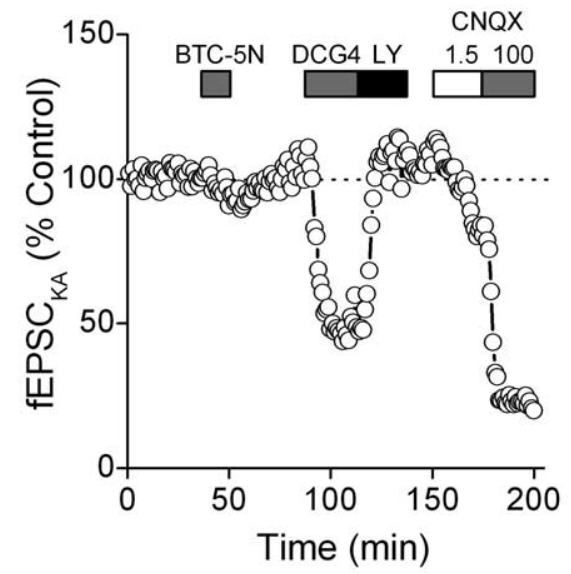

Figure 4. Endogenous zinc limits frequency facilitation of MF-evoked kainate fEPSPs. $\boldsymbol{A}$, Kainate fEPSPs evoked by MF thetapattern stimulation (arrows indicate stimulus bursts) in the presence of bicuculline methochloride (100 $\mu \mathrm{M}), \mathrm{D}-\mathrm{APV}(100 \mu \mathrm{M})$, and GYKI $52466(100 \mu \mathrm{M})$ showed strong frequency facilitation. Application of the zinc chelator BTC-5N (100 $\mu \mathrm{M})$ enhanced this facilitation. CNQX (100 $\mu \mathrm{m}$ ) blocked the fEPSPs. B, Average time course showing potentiation of the last kainate fEPSP of the theta-pattern stimulation train by $100 \mu \mathrm{m}$ BTC-5N and $10 \mathrm{~mm}$ CaEDTA, but not by $2.5 \mathrm{~mm} \mathrm{CaEDTA}(n=4)$. DCG-IV $(1 \mu \mathrm{m})$ and CNQX $(100 \mu \mathrm{m})$ greatly suppressed the fEPSP. C, BTC-5N enhanced frequency facilitation of the kainate fEPSP during thetapattern stimulus trains $(n=8)$. $D$, To measure potentiation on each burst of the train, kainate fEPSPs evoked by each stimulus burst in the presence of BTC- $5 \mathrm{~N}(100 \mu \mathrm{m})$ were compared with the corresponding burst in control. BTC-5N significantly potentiated the kainate fEPSP on the third, fourth, and fifth bursts of the train $\left({ }^{*} p<0.05,{ }^{* *} p<0.01 ; n=8\right)$. The pharmacologically isolated AMPA fEPSP was facilitated during a $5 \mathrm{~Hz}$ train of single pulses; however, BTC-5N did not increase this facilitation. $\boldsymbol{E}$, In mocha mutant mice, BTC-5N (100 $\mu \mathrm{m})$ failed to enhance frequency facilitation of the isolated kainate fEPSP. $\boldsymbol{F}$, Time course from a single experiment showing lack of facilitation of the last MF-evoked kainate fEPSP of the stimulus train by BTC $-5 \mathrm{~N}(100 \mu \mathrm{M})$. The kainate fEPSP was suppressed by DCG-IV $(1 \mu \mathrm{M})$ and this effect was antagonized by LY341495 (3 $\mu \mathrm{M})$. CNQX at a concentration of $100 \mu \mathrm{m}$, but not $1.5 \mu \mathrm{m}$, blocked the kainate fEPSP. G, Averaged responses showing the lack of effect of BTC $-5 \mathrm{~N}$ on the last kainate fEPSP of the theta-pattern stimulus train $(n=4)$. DCG-IV $(1 \mu \mathrm{M})$ and CNQX (100 $\mu \mathrm{m})$ significantly inhibited the kainate fEPSP $\left({ }^{* *} p<0.01\right)$.

concentration of kainate was used to test the effect of zinc on the CA3 antidromic spike. A $100 \mu \mathrm{M}$ concentration of zinc did not block the kainate-mediated depression ( $12 \pm 4 \%$ depression by kainate; $28 \pm 9 \%$ depression by kainate plus zinc; $n=7$ ) (Fig. $5 I$ ). Therefore, kainate receptors on CA3 and MF axons not only differ in their functional effect on axon excitability, they differ in their sensitivity to zinc. Differences in the zinc sensitivity of kai- nate receptors on MFs and CA3 axons could be explained by a variety of mechanisms, including differences in the subunit composition of the expressed kainate receptors.

\section{Subunit-dependent modulation of} recombinant kainate receptors by zinc To understand better the effects of zinc on kainate receptors of different subunit composition, we examined zinc inhibition of recombinant kainate receptors expressed in Xenopus oocytes (Fig. 6). For each kainate receptor, steady-state currents were evoked by a concentration of agonist that yielded a maximal response, and the inhibition produced by increasing concentrations of zinc was measured (Fig. 6A). Zinc inhibition of kainate receptors was compared with zinc inhibition of recombinant NMDA and AMPA receptors. Zinc inhibited all tested receptors and this inhibition rapidly reversed after zinc washout. Zinc inhibition of all tested kainate receptors was monophasic and, except at GluR6R/ $\mathrm{KA} 1$, was complete at the highest zinc concentrations tested (Fig. 6B, C). At GluR6R/ KA1 receptors, zinc inhibition was incomplete reaching a maximum of $67 \pm$ $4 \%$ at $1 \mathrm{~mm}$ zinc (Fig. $6 \mathrm{C}$ ). Zinc inhibited $\mathrm{KA} 1-$ and KA2-containing heteromeric kainate receptors with a higher apparent affinity than it inhibited GluR5 and GluR6 homomeric kainate receptors. In particular, the $\mathrm{IC}_{50}$ for zinc inhibition of GluR6R/ KA1 receptors $(1.5 \pm 0.6 \mu \mathrm{M} ; n=16)$ was $>40$-fold lower than that of GluR6R homomeric receptors $(67 \pm 8 \mu \mathrm{M} ; n=15)$. Zinc inhibited KA1- and KA2-containing kainate receptors with an apparent affinity that was similar to that for zinc inhibition of NR1a/NR2B NMDA receptors $(2.1 \pm$ $0.7 \mu \mathrm{M} ; n=12$ ). In contrast, NR2Ccontaining NMDA receptors as well as GluR2/GluR3 and GluR3 AMPA receptors were markedly less sensitive to zinc than any of the tested kainate receptors (Fig. 6D). GluR5 and GluR6 subunits are subject to RNA editing, which converts a single amino acid residue in the channel pore from a glutamine $(\mathrm{Q})$ into an arginine $(\mathrm{R})$. Editing at this Q/R site in GluR6 did not markedly affect zinc inhibition (Fig. 6D).

To determine whether zinc altered the apparent agonist affinity of the kainate receptor, we tested the effect of $100 \mu \mathrm{M}$ zinc on the domoate concentration-response curve at GluR6R receptors (Fig. $6 \mathrm{E})$. The $\mathrm{EC}_{50}$ for domoate at this receptor $\left(\mathrm{EC}_{50}, 170 \pm\right.$ $16 \mathrm{nM})$ was not altered in the presence of zinc $\left(\mathrm{EC}_{50}, 190 \pm 30\right.$ $\mathrm{nM})$, suggesting that zinc acts in a noncompetitive manner.

Zinc could influence the amplitude of steady-state current in oocytes by altering desensitization of the kainate receptor. To test this possibility, concanavalin $\mathrm{A}(\mathrm{Con} \mathrm{A} ; 0.3 \mathrm{mg} / \mathrm{ml})$ was perfused 
onto each oocyte for $3 \mathrm{~min}$ to reduce kainate receptor desensitization (Egebjerg et al., 1991). If zinc inhibition of kainate receptors results from an enhancement of desensitization, then Con A should reduce zinc inhibition. However, at both GluR6R (data not shown) and GluR6R/KA2 receptors (Fig. 6 F), we found that Con A had no effect on zinc inhibition. These results indicate that zinc does not inhibit kainate receptors by enhancing desensitization.

\section{Voltage dependence of zinc inhibition}

The voltage sensitivity of zinc inhibition was examined to determine whether zinc inhibits kainate receptors by acting at a site within the transmembrane electric field. Agonist-evoked currents were recorded from oocytes as the holding potential was ramped from -100 to $+50 \mathrm{mV}$. In the absence of zinc, the current-voltage relationship from oocytes expressing GluR6R, GluR6R/KA1, or GluR6R/KA2 was linear or weakly outwardly rectifying and reversed close to $0 \mathrm{mV}$ (Fig. 7A). Conductance-voltage $(G-V)$ relationships normalized to responses at $-100 \mathrm{mV}$ revealed that the $+50 \mathrm{mV} /-60 \mathrm{mV}$ rectification ratio for GluR6 $(2.07 \pm 0.07 ; n=8)$, GluR6R/KA1 (1.76 $\pm 0.03 ; n=6)$, and GluR6R/KA2 (1.39 $\pm 0.04 ; n=4)$ were similar to values reported previously (Bowie and Mayer, 1995; Kamboj et al., 1995; Pemberton et al., 1998; Cui and Mayer, 1999). We evaluated the effect of zinc by expressing the $G-V$ relationship in the presence of different concentrations of zinc relative to that in the absence of zinc (Fig. $7 B$ ). The resulting curves were then used to determine the $\mathrm{IC}_{50}$ for zinc at each membrane potential (Fig. 7C). We measured the voltage dependence of zinc inhibition by comparing the zinc $\mathrm{IC}_{50}$ at -60 $\mathrm{mV}$ with that at $+50 \mathrm{mV}$ (Fig. $7 D$ ). All receptor combinations tested showed less than a twofold change in zinc inhibition at -60 and $+50 \mathrm{mV}$. At GluR6R and GluR6R/KA2 receptors, the change in zinc inhibition was significantly different $(p<$ 0.01 ) but small, indicating that the majority of zinc inhibition occurred through a voltage-independent mechanism. These observations indicate little voltage dependence of zinc inhibition at the tested kainate receptors.

Zinc inhibition of other glutamate receptors was similarly voltage independent. At all tested NMDA receptors (NR1a/ NR2A, NR1a/NR2B, and NR1b/NR2C) zinc inhibition was primarily voltage independent over the range of zinc concentrations tested. This lack of voltage dependence agrees with previous findings (Chen et al., 1997; Paoletti et al., 1997; Traynelis et al., 1998). Similarly, we found that the very
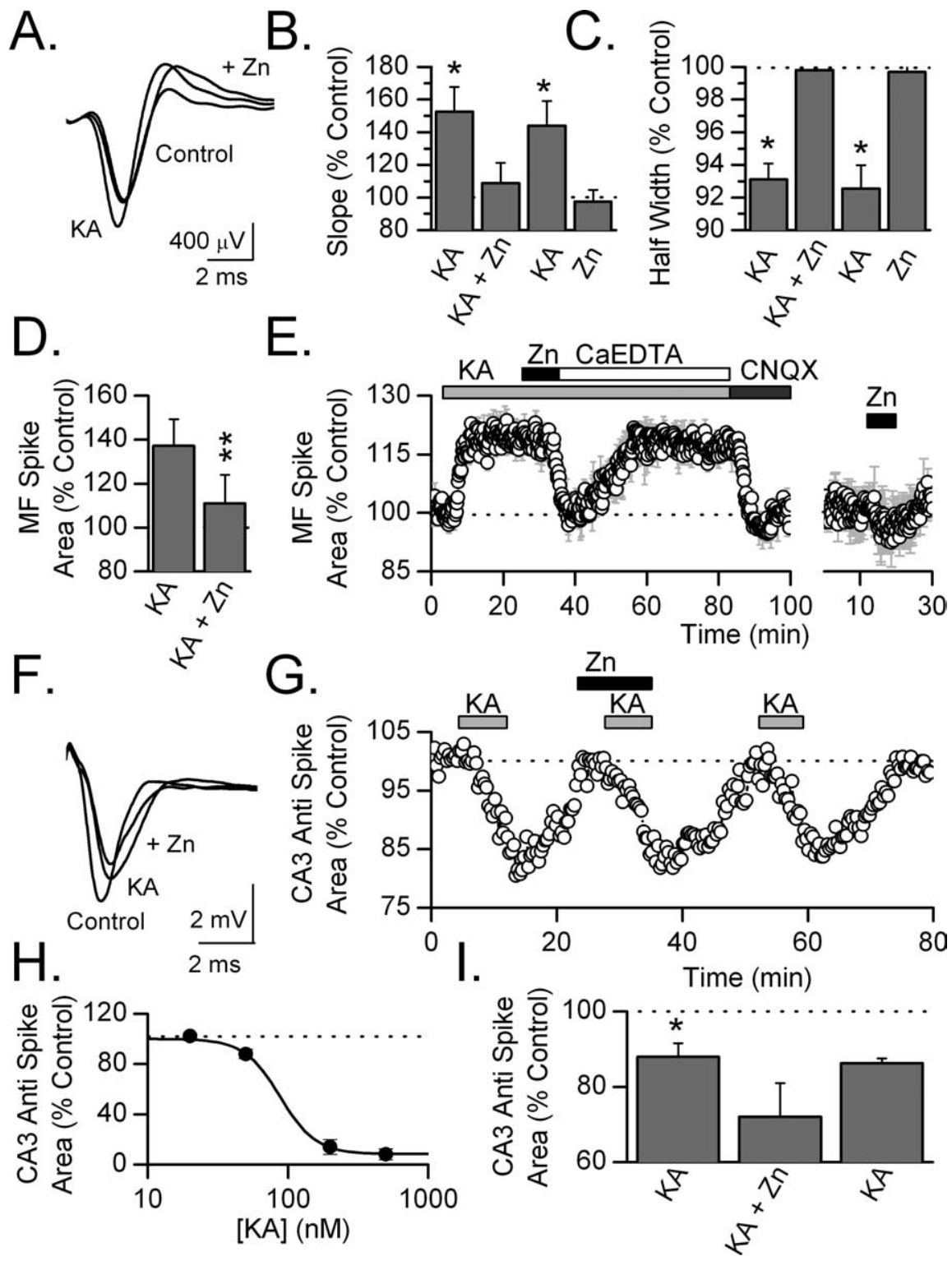

Figure 5. Zinc suppresses the facilitatory but not inhibitory effects of kainate on axon excitability. $A$, The MF antidromic spike was facilitated by $500 \mathrm{~nm}$ kainate. Zinc $(100 \mu \mathrm{m})$ reversed this facilitation. To isolate kainate receptors, the MF spike was recorded in the presence of $100 \mu \mathrm{m}$ each of bicuculline methochloride, D-APV, CaEDTA, and GYKI 52466. B, C, Kainate (500 nm) potentiated the rising slope $(\boldsymbol{B} ; 20-80 \%)$ and decreased the half-width $(\boldsymbol{C})$ of the MF spike, suggesting that it potentiated the spike amplitude by enhancing the synchrony of the response $\left({ }^{*} p<0.05 ; n=5\right)$. Zinc $(100 \mu \mathrm{m})$ blocked these effects of kainate. In contrast, zinc applied alone influenced neither of these measures. $\boldsymbol{D}$, Kainate potentiated the area of the MF antidromic spike. Zinc significantly blocked this potentiation $\left({ }^{* *} p<0.01 ; n=5\right)$. $\boldsymbol{E}$, Averaged time course of four experiments showing potentiation of the area of the MF antidromic spike by $500 \mathrm{~nm}$ kainate. Zinc (100 $\mu \mathrm{m}$ free zinc; $200 \mu \mathrm{m}$ total zinc added) blocked this potentiation. Increasing the concentration of CaEDTA to $500 \mu \mathrm{m}$ reversed the effect of zinc. CNQX (100 $\mu \mathrm{m}$ ) blocked the kainateinduced potentiation. Zinc in the absence of kainate (100 $\mu \mathrm{m}$ free zinc; $200 \mu \mathrm{m}$ total zinc added) had no significant effect on the area of the MF antidromic spike $(n=4) . F, A t C A 3$ axons, $50 \mathrm{~nm}$ kainate inhibited the antidromic spike recorded in the CA3 cell body layer. In these experiments, kainate receptors were pharmacologically isolated, as described above. Kainate decreased the rising slope of the antidromic spike and increased its half-width, indicating that it decreased firing synchrony. Zinc ( $100 \mu \mathrm{m}$ free zinc; 200 $\mu \mathrm{m}$ total zinc added) slightly potentiated the depressant effect of kainate. $\mathbf{G}$, Time course of an experiment showing the depression of the area of the $C A 3$ antidromic spike produced by kainate $(50 \mathrm{~nm})$ and the inability of zinc (100 $\mu \mathrm{m}$ free zinc) to block this depression. $\boldsymbol{H}$, Concentration response curve for kainate on the $C A 3$ antidromic spike $\left(\mathrm{IC}_{50}, 84 \pm 20 \mathrm{~nm}\right)$. Even low concentrations of kainate, which facilitated MF spikes, depressed CA3 antidromic spikes. I, Kainate $(50 \mathrm{~nm})$ significantly depressed the area of the $C A 3$ antidromic spike $\left({ }^{*} p<0.05 ; n=7\right)$.Zinc (100 $\mu$ m free zinc) did not reverse, but slightly potentiated, this depression.

weak zinc inhibition (1-1000 $\mu \mathrm{M})$ of GluR2/GluR3 AMPA receptors was voltage independent. These results are consistent with a modulatory effect of zinc on glutamate receptors at a site outside the channel pore as has been previously suggested (Paoletti et al., 1997). 
A.

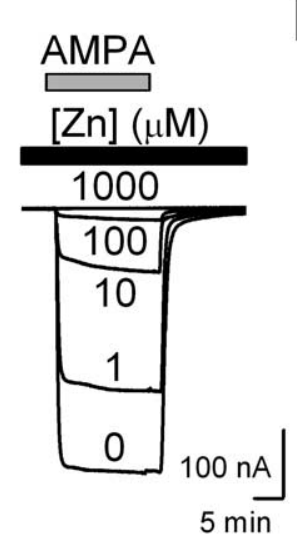

B.

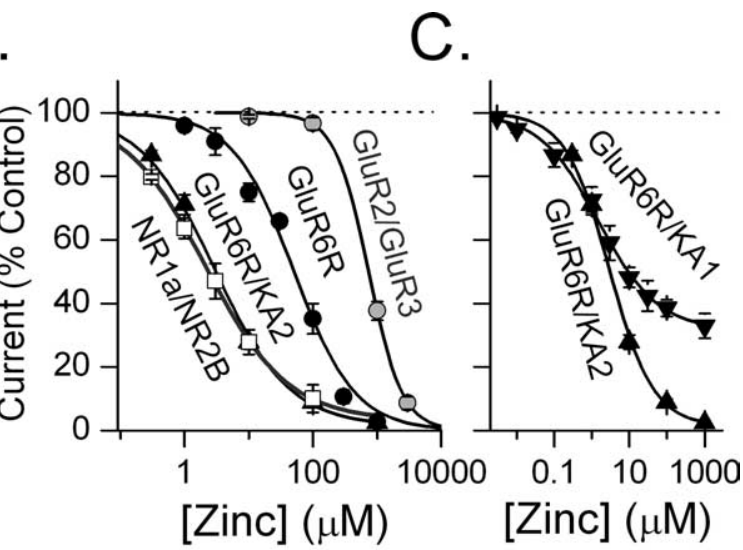

D.
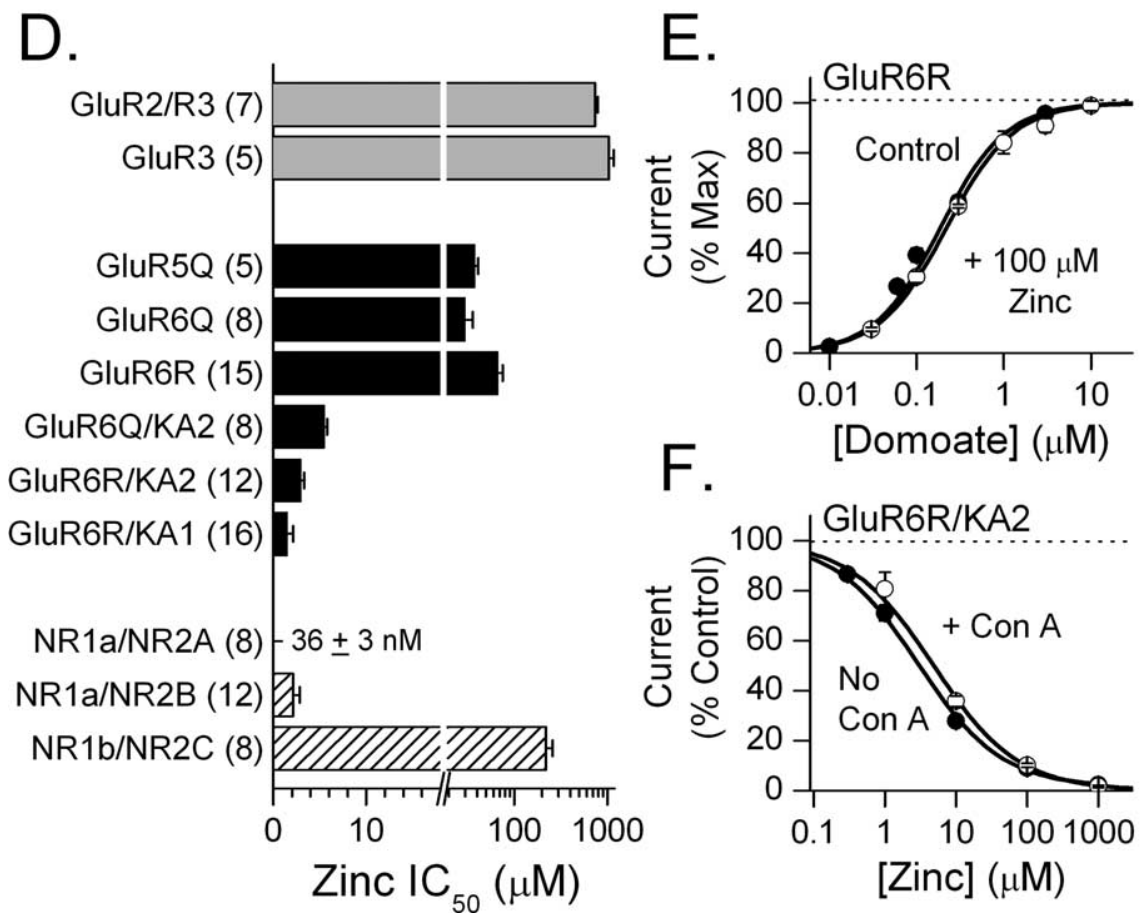

Figure 6. Zinc inhibition of recombinant kainate receptors is subunit dependent. $A$, Zinc inhibits currents evoked by AMPA (30 $\mu \mathrm{M}$ ) from an 0ocyte expressing GluR6R/KA2 receptors. Zinc was applied (black bar) at the concentration indicated above each current trace. $\boldsymbol{B}$, Concentration-response curves for zinc inhibition of current from oocytes expressing each of the indicated receptors. Zinc inhibition of the kainate receptor-mediated current depended on the subunit composition of the kainate receptor with GluR6R/KA2 receptors $(n=12)$ being more sensitive to zinc than GluR6R receptors $(n=15)$. GluR6R/KA2 receptors were similar to NR1a/NR2B receptors $(n=12)$ in their zinc sensitivity. $C$, Maximal zinc inhibition of current at GluR6R/KA2 receptors was greater than that at GluR6R/KA1 receptors $(n=16)$. $\boldsymbol{D}$, The half-maximal concentration at which zinc inhibited each of the indicated receptors is shown. The presence of the KA1 or KA2 subunit markedly increased the sensitivity of kainate receptors to zinc. The number of oocytes tested for each receptor is shown in parentheses. $\boldsymbol{E}$, Zinc did not alter the apparent affinity of GluR6R receptors for domoate (control, $n=7 ;$ zinc, $n=8$ ). Currents are normalized to the maximal current at $10 \mu \mathrm{m}$ domoate in each condition. $\boldsymbol{F}$, Reducing desensitization by adding con $\mathrm{A}(0.3 \mathrm{mg} / \mathrm{ml})$ did not alter zinc inhibition of current at GluR6R/KA2 receptors (control, $n=12$; Con $\mathrm{A}, n=6$ ).

\section{Proton sensitivity of zinc inhibition}

Brain $\mathrm{pH}$ is dynamic and can change markedly during neuronal activity and in pathological conditions. Zinc inhibits NR1a/ NR2A NMDA receptors partly by enhancing proton inhibition (Low et al., 2000). We have shown previously that protons tonically inhibit kainate receptors (Mott et al., 2003). Given the dynamic nature of proton concentrations in the brain, an interaction between protons and zinc would be of importance in understanding the physiological effects of zinc. To evaluate the functional interaction between proton and zinc inhibition, we measured the zinc sensitivity of kainate receptors at different $\mathrm{pH}$ levels (Fig. 8A). Zinc inhibition curves were normalized and the effect of protons on zinc $\mathrm{IC}_{50}$ values compared. In contrast to NR1/NR2A receptors, we found that GluR6R kainate receptors were less sensitive to zinc at acidic $\mathrm{pH}$. Protons caused a rightward shift in the zinc inhibition curve, shifting the $\mathrm{IC}_{50}$ for zinc inhibition of this receptor 2.1-fold from $67 \pm 8 \mu \mathrm{M}$ at $\mathrm{pH} 7.5$ $(n=15)$ to $142 \pm 15 \mu \mathrm{M}$ at $\mathrm{pH} 6.7(n=7)$. These results indicate that protons suppress zinc inhibition of kainate receptors.

KA1 and KA2 subunits markedly enhanced the zinc sensitivity of the kainate receptor. We tested the effect of protons on kainate receptors containing these subunits (Fig. 8B,C). At GluR6R/KA1 receptors, an increase in proton concentration from $\mathrm{pH} 7.5$ to $\mathrm{pH} 6.7$ caused a 2.1-fold rightward shift in the $\mathrm{IC}_{50}$ for zinc (Fig. $8 B)$. The extent of this shift was similar to that observed for GluR6 homomeric receptors. Recalling that zinc inhibition for GluR6/KA1 receptor channels was incomplete (Figs. 6C, $8 B$ ), we noticed that decreasing the $\mathrm{pH}$ caused an increase in the amplitude of the residual current observed in $1 \mathrm{~mm}$ zinc, as would be expected if protons suppressed zinc inhibition.

Protons produced a much greater increase in the $\mathrm{IC}_{50}$ for zinc inhibition of GluR6R/KA2 receptors than for either GluR6R or GluR6R/KA1 receptors (Fig. $8 C)$. At these receptors, the $\mathrm{IC}_{50}$ for zinc inhibition shifted ninefold between $\mathrm{pH} 7.5$ $\left(\mathrm{IC}_{50}, 3 \pm 0.4 \mu \mathrm{M} ; n=6\right)$ and $\mathrm{pH} 6.7\left(\mathrm{IC}_{50}\right.$, $27 \pm 2 \mu \mathrm{M} ; n=5)$. The strong reduction in zinc sensitivity at low $\mathrm{pH}$ suggests that proton concentration is an important determinant of the zinc sensitivity of these heteromeric kainate receptors.

To better understand the interaction of protons and zinc, we evaluated the effect of different concentrations of zinc on proton inhibition of GluR6R/KA2 receptors (Fig. $8 D$ ). In the absence of zinc, protons inhibited the receptor (Mott et al., 2003). In the presence of zinc, current at GluR6R/KA2 receptors was also inhibited. However, protons potentiated this current by relieving zinc inhibition. The extent of the potentiation depended on both the proton and zinc concentration. For example, as the zinc concentration was increased, greater concentrations of protons were required to relieve zinc inhibition. Thus, the half-maximal concentration of protons necessary to relieve zinc inhibition shifted from near $\mathrm{pH}$ 8 at $1 \mu \mathrm{M}$ zinc to about $\mathrm{pH} 6.8$ at $100 \mu \mathrm{M}$ zinc. These findings suggest that at physiological $\mathrm{pH}, \mathrm{pH} 7.3$, zinc inhibition of kainate receptors would be tonically regulated by protons. Thus, in the presence of zinc kainate receptor-mediated currents can be potentiated as much as threefold with an acidic shift from $\mathrm{pH} 7.5$ to $\mathrm{pH} 6.7$ (Fig. $8 \mathrm{E}$ ). These experiments indicate that the effect of a decrease in $\mathrm{pH}$ on kainate receptor current depends on both the 
composition of the kainate receptor and the concentration of zinc.

These results predict that the zinc sensitivity of native kainate receptors will depend on $\mathrm{pH}$. To test this possibility, we compared the zinc dose-response curve at $\mathrm{pH} 7.4$ with that at $\mathrm{pH} 6.7$ for inhibition of the mossy fiber kainate EPSC in CA3 pyramidal neurons. As predicted, protons caused a large rightward shift in the zinc dose-response curve, shifting the zinc $\mathrm{IC}_{50}$ from $15 \pm 2 \mu \mathrm{M}$ at $\mathrm{pH} 7.4$ to $221 \pm 62 \mu \mathrm{M}$ at $\mathrm{pH}$ 6.7, a 15-fold shift (data not shown). The magnitude of this shift was similar to that reported for recombinant GluR6R/ $\mathrm{KA} 2$ receptors, suggesting that these native postsynaptic receptors contained the KA2 subunit.

\section{Discussion}

The principal finding of this study is that kainate receptors are inhibited by endogenous zinc in a $\mathrm{pH}$-dependent manner. During theta-pattern stimulation, synaptically released zinc limits frequency facilitation of kainate fEPSPs at mossy fiber synapses. The effect of released zinc is selective for postsynaptic kainate receptors, as synaptic AMPA responses were unaffected by zinc chelation. Physiologically relevant concentrations of applied zinc selectively suppressed kainate, but not AMPA receptor EPSCs. Zinc also suppressed kainate receptors responsible for the facilitatory effect of kainate on mossy fiber excitability. In contrast, zinc did not block the kainate receptors responsible for the depressive effect of kainate on CA3 axon excitability.

We found that zinc inhibition was subunit dependent with recombinant receptors containing the KA1 or KA2 subunit being the most zinc sensitive $\left(\mathrm{IC}_{50}, 1.5-5\right.$ $\mu \mathrm{M})$. Similarly, postsynaptic kainate receptors on CA3 pyramidal cells and kainate receptors on mossy fiber axons were strongly inhibited by zinc. These native receptors were reported to contain KA2 subunits in studies using $\mathrm{KA} 2^{-1-}$ mice (Contractor et al., 2003).

Zinc inhibition of recombinant kainate receptors was strongly affected by $\mathrm{pH}$. Protons suppressed zinc inhibition at all tested kainate receptors. Protons and zinc interacted most strongly at receptors containing the KA2 subunit. At these receptors zinc inhibition was tonically suppressed at physiological $\mathrm{pH}$. Tonic regulation of zinc sensitivity by protons suggests that both the alkaline and acid shifts in interstitial $\mathrm{pH}$ that accompany neuronal activity could regulate zinc inhibition. For example, at alkaline $\mathrm{pH}$ ( $\mathrm{pH} 8.3$ ), GluR6R/KA2 receptors were substantially inhibited by nanomolar concentrations of zinc. Thus, the functional impact of zinc inhibition on synaptic kainate receptors will depend on the concentration of both zinc and protons as well as the subunit composition of the receptor. The com-
B.

Zinc $(\mu \mathrm{M})$

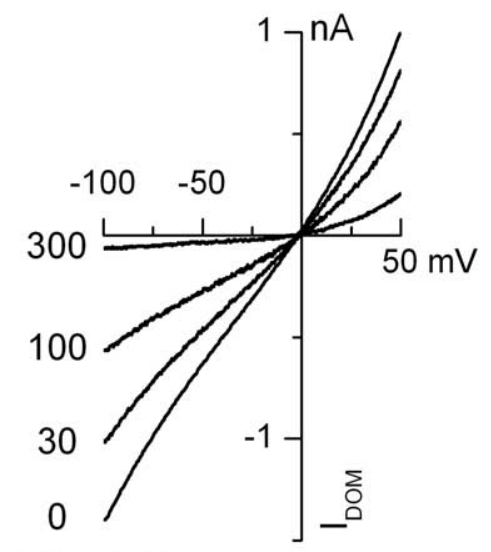

Zinc $(\mu \mathrm{M})$

C.

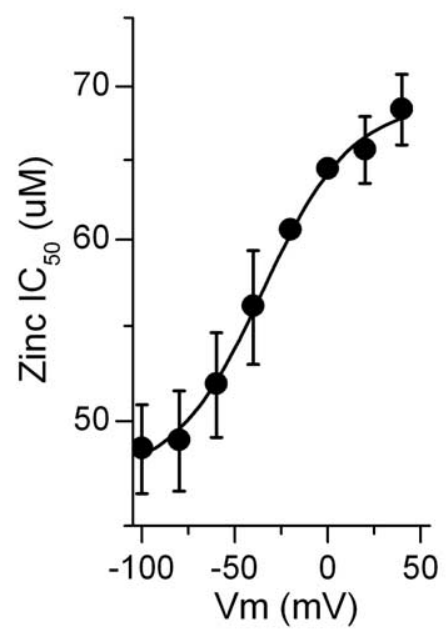

D.

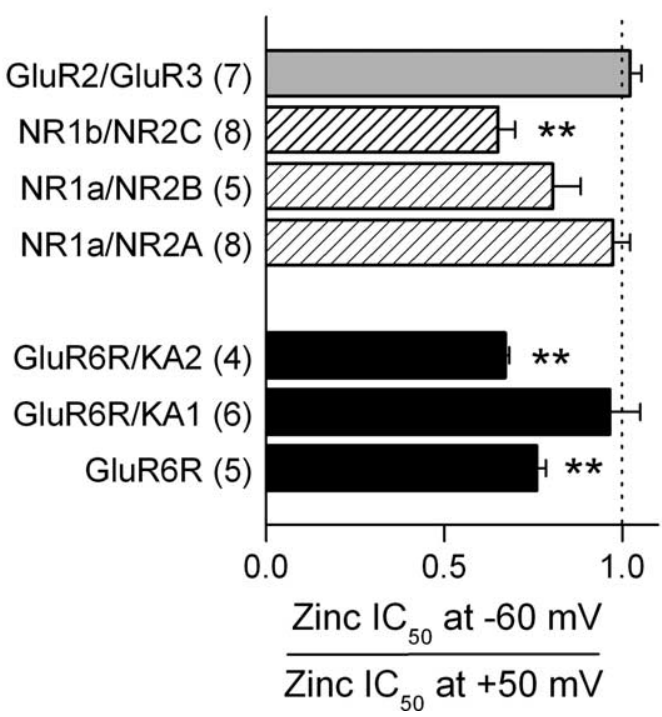

Figure 7. Voltage dependence of zinc inhibition. $\boldsymbol{A}$, Current-voltage curves of GluR6R generated by ramping the holding voltage from -100 to $+50 \mathrm{mV}$ in a single 00 cyte. Zinc inhibited the current somewhat more strongly at negative potentials. $\boldsymbol{B}$ Conductance voltage plot for inhibition of GluR6R current at the indicated concentrations of zinc. The conductance of the current in zinc is expressed as a fraction of the conductance at that holding potential in control. $\boldsymbol{C}$, The half-maximal concentration at which zinc inhibited the GluR6R current was calculated from the conductance voltage plot at each membrane potential $(n=5)$. The apparent affinity of the GluR6R receptor for zinc was greater at negative holding potentials. $D$, The voltage sensitivity of zinc inhibition for each of the indicated receptors is expressed as the ratio of the zinc $\mathrm{IC}_{50}$ at $-60 \mathrm{mV}$ to that at $+50 \mathrm{mV}$. The number of oocytes tested for each receptor is shown in parentheses. Zinc inhibition at all tested receptors was predominantly voltage independent. However, a weak but significant voltage-dependent component of inhibition was present at NR1b/NR2C, GluR6R/ KA2, and GluR6R receptors ( $\left.{ }^{* *} p<0.01\right)$.

plex interplay between these factors will determine the relative contribution of kainate receptors to mossy fiber transmission.

\section{Role of zinc in synaptic physiology}

Zinc chelators enhanced the kainate fEPSP by removing zinc inhibition. This conclusion is strengthened by the fact that two structurally dissimilar chelators produced a similar effect. BTC$5 \mathrm{~N}$, a low-affinity chelator, was more effective than CaEDTA in relieving zinc inhibition of synaptic kainate receptors, possibly because BTC-5N binds zinc more rapidly than CaEDTA and therefore is able to act within the time frame of synaptic zinc release.

The ability of zinc chelation to enhance frequency facilitation 


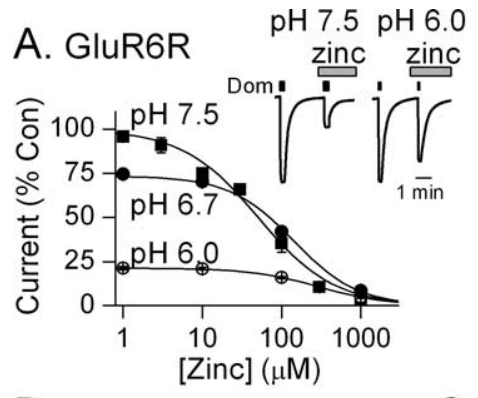

\section{B. GluR6R/KA1}

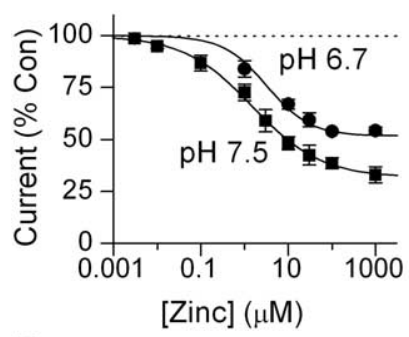

D. GluR6R/KA2

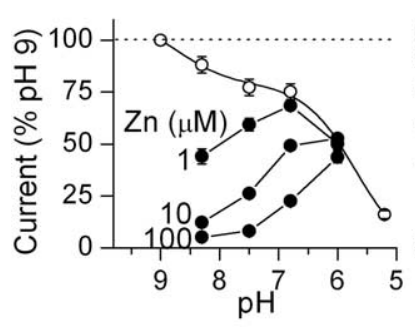

\section{E.}

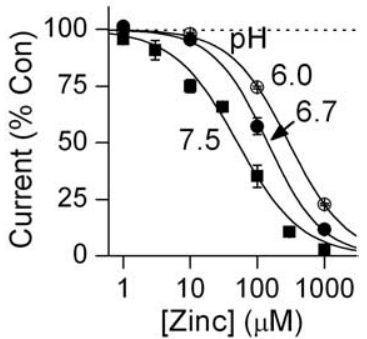

\section{GluR6R/KA2}
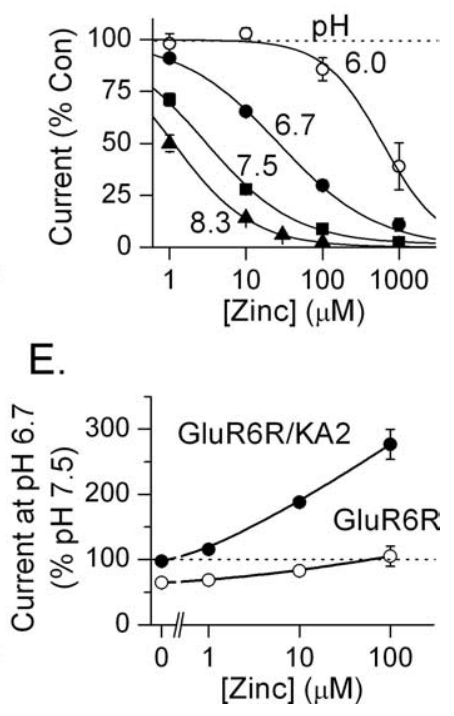

Figure 8. Protons relieve zinc inhibition of kainate receptors. $\boldsymbol{A}$, Left, At GluR6R receptors, protons inhibited the current but relieved zinc inhibition as the $\mathrm{pH}$ was lowered from $7.5-6.0$

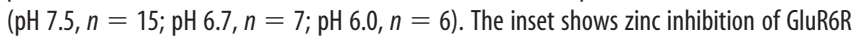
currents at pH 7.5 and 6.0. The currents at pH 6.0 were scaled to those at pH 7.5 to better demonstrate the loss of zinc inhibition. Right, Here and in $\boldsymbol{B}$ and $\boldsymbol{C}$ the zinc inhibition curves at each $\mathrm{pH}$ were normalized to the control current at that $\mathrm{pH}$. Decreasing the $\mathrm{pH}$ from 7.5 to 6.0 decreased the sensitivity of the receptor to zinc inhibition. $\boldsymbol{B}$, At GluR6R/KA1 receptors, protons increased the zinc $\mathrm{IC}_{50}$ and decreased the maximal inhibition produced by zinc $\left(\mathrm{pH} 7.5, \mathrm{IC}_{50}\right.$, $1.5 \pm 0.6 \mu \mathrm{m} ; n=16 ; \mathrm{pH} 6.7, \mathrm{IC}_{50}, 3.2 \pm 0.9 \mu \mathrm{m} ; n=5$ ). The shift in zinc sensitivity was similar to that at GluR6R receptors. C, At GluR6R/KA2 receptors, protons caused a much greater shift in zinc sensitivity than at GluR6R receptors ( $\mathrm{pH} 8.3, \mathrm{IC}_{50}, 1.0 \pm 0.2 \mu \mathrm{m} ; n=6 ; \mathrm{pH} 7.5, \mathrm{IC}_{50 \prime}$ $\left.3.0 \pm 0.4 \mu \mathrm{m} ; n=6 ; \mathrm{pH} 6.7, \mathrm{IC}_{50}, 27 \pm 2 \mu \mathrm{m} ; n=5 ; \mathrm{pH} 6.0, \mathrm{IC}_{50}, 610 \pm 210 \mu \mathrm{m} ; n=6\right) . D$, In the absence of zinc, protons inhibited GluR6/KA2 receptors, but in the presence of zinc, protons potentiated the current by removing zinc inhibition. At each $\mathrm{pH}$, current amplitude in the presence of zinc is expressed as a percentage of the current at $\mathrm{pH} 9$ in the absence of zinc. At selected pHs, the current amplitude in the absence of zinc (open circles) and in the presence of the indicated zinc concentration (filled circles) is shown. $\boldsymbol{E}$, In the presence of zinc, decreasing $\mathrm{pH}$ from 7.5 to 6.7 potentiated current at GluR6R/KA2 receptors (solid circles; $n=5$ ) more than current at GluR6 receptors (open circles; $n=7$ ). The amplitude of the current at pH 6.7 is expressed as a percentage of the current at $\mathrm{pH} 7.5$ in each of the indicated concentrations of zinc.

of the kainate fEPSP suggests that during the theta-pattern train, zinc accumulates at mossy fiber synapses. The build-up of zinc progressively increases inhibition of kainate receptors. This conclusion is in agreement with studies using a variety of techniques, including fluorescent zinc indicators that have found increased zinc concentrations in the microenvironment of mossy fiber terminals after mossy fiber stimulation (Assaf and Chung, 1984; Howell et al., 1984; Li et al., 2001b; Ueno et al., 2002; QuintaFerreira et al., 2004; Frederickson et al., 2005, 2006a). Furthermore, numerous studies have found effects of released zinc on synaptic currents mediated by NMDA (Vogt et al., 2000; Ueno et al., 2002), GABA (Smart et al., 1994), and glycine (Bloomenthal et al., 1994; Laube et al., 1995; Hirzel et al., 2006). The ability of zinc chelators to influence the function of these receptors provides strong support for the activity dependent release of zinc at synapses.

The ability of released zinc to regulate synaptic transmission appears to be widespread across multiple strains and species of animal. Endogenously released zinc modulates mossy fiber responses in mouse (Vogt et al., 2000; Dominguez et al., 2006), guinea pig (Ruiz et al., 2004), and rat (Molnar and Nadler, 2001; Ueno et al., 2002; Matias et al., 2006). We found that zinc chelators potentiate mossy-fiber-evoked kainate responses in rat. To provide additional support for a role of endogenous zinc in regulating synaptic kainate responses, we examined the effect of BTC- $5 \mathrm{~N}$ on kainate fEPSPs in mocha mutant mice. Mocha mutant mice express a natural mutation that results in loss of the ZnT3 zinc transporter from synaptic vesicles, causing the mossy fibers to fail to accumulate zinc (Kantheti et al., 1998; Vogt et al., 2000). In these mocha mutants, BTC-5N did not enhance the kainate response during theta-pattern stimulus trains, suggesting that the lack of mossy fiber zinc prevented potentiation by the zinc chelator. Although wild-type mice were not tested, these findings in mocha mutant mice are consistent with our suggestion that endogenously released zinc regulates synaptic kainate responses.

Our data provide evidence that the release of zinc during burst activation of mossy fiber terminals limits the activation of synaptic kainate receptors. The slow time course of kainate EPSPs at mossy fiber synapses suggests that summation of these responses during sustained afferent activity may increase depolarization of CA3 pyramidal cells, enhancing excitability in this network (Frerking and Ohliger-Frerking, 2002). Accordingly, kainate receptors at mossy fiber synapses have been implicated in the development of seizures (Ben-Ari and Cossart, 2000). Zinc inhibition could therefore act as a brake that prevents pathological activation of mossy fiber kainate receptors that would otherwise promote synchronized firing within the recurrent CA3 network.

A previous study (Lin et al., 2001) reported that zinc (50-200 $\mu \mathrm{M})$ potentiated AMPA currents in about half of the neurons tested. At the concentrations used in our study we found no effect of zinc on synaptic AMPA responses in hippocampal slices. At recombinant receptors we found that high concentrations of zinc $(>500 \mu \mathrm{M})$ were necessary to inhibit AMPA receptors. This finding agrees with an earlier study that reported AMPA receptor inhibition by high zinc concentrations $(>500 \mu \mathrm{M})$ (Mayer et al., 1989). At low concentrations, zinc mildly potentiates AMPA responses both at native (Mayer et al., 1989; Lin et al., 2001) and recombinant receptors (Dreixler and Leonard, 1994). At recombinant receptors, the potentiating effect of zinc was confined to GluR3 receptors and was only observed over a narrow range of zinc concentrations $(4-7.5 \mu \mathrm{M})$, which were not explored here.

\section{Kainate receptor modulation}

Like NMDA receptors, kainate receptors are regulated by several endogenous substances in addition to zinc, such as protons and polyamines (Mott et al., 2003). Kainate receptors containing KA1 or KA2 subunits are markedly more sensitive to each of these modulators. Whereas KA1 and KA2 subunits enhance the sensitivity of kainate receptors to modulation, important differences exist in the response of KA1 and KA2-containing receptors to each of the endogenous regulators. For example, KA1 containing receptors were potentiated by protons, whereas all other kainate receptors were inhibited (Mott et al., 2003). In contrast, zinc inhibition of KA2 containing kainate receptors was markedly more proton sensitive than other kainate receptors. Thus, recep- 
tor subunit composition plays an important role in determining the response of these receptors to endogenous regulators. Given the specialized roles of kainate receptors of different subunit composition (Castillo et al., 1997; Mulle et al., 2000; Contractor et al., 2003), our results indicate that endogenous modulatory agents will differentially regulate distinct kainate receptors and thereby exert selective influence over discrete aspects of kainate neurotransmission. These modulatory sites may also provide novel sites for the development of context-dependent and region-selective neuroprotective agents (Mott et al., 1998).

\section{Interaction between zinc and protons}

The $\mathrm{pH}$ dependence of zinc inhibition suggests an interaction between protons and zinc at the kainate receptor. Protonation of a zinc-coordinating amino acid in the kainate receptor could reduce the affinity of the zinc binding site. Alternatively, protons and zinc could converge on the same allosteric mechanism for kainate receptor inhibition, with protons being less efficacious than zinc. The situation differs from NR1/NR2A NMDA receptors where zinc enhances proton inhibition (Choi and Lipton, 1999; Low et al., 2000). However, at both kainate and NR1/NR2A NMDA receptors channel function is inhibited with sufficient protons or zinc.

The interaction between protons and zinc has interesting implications for kainate receptor regulation. Protons reduced zinc inhibition at each kainate receptor tested, with the effect being strongest for GluR6R/KA2 receptors. At GluR6R/KA2 receptors zinc sensitivity changed 600 -fold over the tested $\mathrm{pH}$ range. Thus, at an acidic $\mathrm{pH}$, GluR6R/KA2 receptors were less sensitive to zinc than GluR6 homomeric receptors, whereas at an alkaline $\mathrm{pH}$, these receptors were sensitive to submicromolar zinc concentrations, much more zinc sensitive than GluR6 receptors. The proton sensitivity of zinc inhibition falls within the physiological $\mathrm{pH}$ range, indicating that zinc inhibition of these receptors is tonically regulated by protons.

Interestingly, the interaction between protons and zinc produces functionally different effects on kainate and NMDA receptors. Thus, an alkaline shift in $\mathrm{pH}$, as occurs during synaptic transmission, would be expected to enhance zinc inhibition of postsynaptic kainate receptors (Fig. $8 C$ ) but reduce inhibition of NMDA receptors by zinc (Low et al., 2000). Alternatively, during focal acidic conditions that accompany seizures or ischemia, NMDA currents would be inhibited synergistically by protons and zinc, whereas zinc inhibition of kainate receptors would be relieved. Thus, by differentially altering zinc inhibition, acidic $\mathrm{pH}$ would increase the prominence of kainate signaling relative to NMDA signaling. The increase in kainate receptor-mediated current may contribute to network hyperexcitability during these pathological situations.

\section{References}

Alt A, Weiss B, Ogden AM, Knauss JL, Oler J, Ho K, Large TH, Bleakman D (2004) Pharmacological characterization of glutamatergic agonists and antagonists at recombinant human homomeric and heteromeric kainate receptors in vitro. Neuropharmacology 46:793-806.

Assaf SY, Chung SH (1984) Release of endogenous $\mathrm{Zn}^{2+}$ from brain tissue during activity. Nature 308:734-736.

Ben-Ari Y, Cossart R (2000) Kainate, a double agent that generates seizures: two decades of progress. Trends Neurosci 23:580-587.

Bloomenthal AB, Goldwater E, Pritchett DB, Harrison NL (1994) Biphasic modulation of the strychnine-sensitive glycine receptor by zinc. Mol Pharmacol 46:1156-1159.

Bortolotto ZA, Clarke VR, Delany CM, Parry MC, Smolders I, Vignes M, Ho KH, Miu P, Brinton BT, Fantaske R, Ogden A, Gates M, Ornstein PL,
Lodge D, Bleakman D, Collingridge GL (1999) Kainate receptors are involved in synaptic plasticity. Nature 402:297-301.

Bowie D, Mayer ML (1995) Inward rectification of both AMPA and kainate subtype glutamate receptors generated by polyamine-mediated ion channel block. Neuron 15:453-462.

Brooks SPJ, Storey KB (1992) Bound and determined: a computer program for making buffers of defined ion concentrations. Anal. Biochem 201:119-126.

Castillo PE, Malenka RC, Nicoll RA (1997) Kainate receptors mediate a slow postsynaptic current in hippocampal CA3 neurons. Nature 388:182-186.

Chen N, Moshaver A, Raymond LA (1997) Differential sensitivity of recombinant $N$-methyl-D-aspartate receptor subtypes to zinc inhibition. Mol Pharmacol 51:1015-1023.

Choi YB, Lipton SA (1999) Identification and mechanism of action of two histidine residues underlying high-affinity $\mathrm{Zn}^{2+}$ inhibition of the NMDA receptor. Neuron 23:171-180.

Clemens JD (1996) Transmitter timecourse in the synaptic cleft: its role in central synaptic function. Trends Neurosci 19:163-171.

Cole TB, Wenzel HJ, Kafer KE, Schwartzkroin PA, Palmiter RD (1999) Elimination of zinc from synaptic vesicles in the intact mouse brain by disruption of the ZnT3 gene. Proc Natl Acad Sci USA 96:1716-1721.

Contractor A, Sailer AW, Darstein M, Maron C, Xu J, Swanson GT, Heinemann SF (2003) Loss of kainate receptor-mediated heterosynaptic facilitation of mossy-fiber synapses in KA2-/- mice. J Neurosci 23:422-429.

Cossart R, Epsztein J, Tyzio R, Becq H, Hirsch J, Ben-Ari Y, Crepel V (2002) Quantal release of glutamate generates pure kainate and mixed AMPA/ kainate EPSCs in hippocampal neurons. Neuron 35:147-159.

Cui C, Mayer ML (1999) Heteromeric kainate receptors formed by the coassembly of GluR5, GluR6, and GluR7. J Neurosci 19:8281-8291.

Dingledine R, Borges K, Bowie D, Traynelis SF (1999) The glutamate receptor ion channels. Pharmacol Rev 51:7-62.

Dominguez MI, Blasco-Ibanez JM, Crespo C, Nacher J, Marques-Mari AI, Martinez-Guijarro FJ (2006) Neural overexcitation and implication of NMDA and AMPA receptors in a mouse model of temporal lobe epilepsy implying zinc chelation. Epilepsia 47:887-899.

Dreixler JC, Leonard JP (1994) Subunit-specific enhancement of glutamate receptor responses by zinc. Brain Res Mol Brain Res 22:144-150.

Egebjerg J, Bettler B, Hermans-Borgmeyer I, Heinemann S (1991) Cloning of a cDNA for a glutamate receptor subunit activated by kainate but not AMPA. Nature 351:745-748.

Fletcher EJ, Lodge D (1996) New developments in the molecular pharmacology of alpha-amino-3-hydroxy-5-methyl-4-isoxazole propionate and kainate receptors. Pharmacol Ther 70:65-89.

Frederickson CJ, Danscher G (1990) Zinc-containing neurons in hippocampus and related CNS structures. Prog Brain Res 83:71-84.

Frederickson CJ, Suh SW, Silva D, Frederickson CJ, Thompson RB (2000) Importance of zinc in the central nervous system: the zinc-containing neuron. J Nutr 130:1471S-1483S.

Frederickson CJ, Koh JY, Bush AI (2005) The neurobiology of zinc in health and disease. Nat Rev Neurosci 6:449-462.

Frederickson CJ, Giblin III LJ, Balaji RV, Masalha R, Frederickson CJ, Zeng Y, Lopez EV, Koh JY, Chorin U, Besser L, Hershfinkel M, Li Y, Thompson RB, Krezel A (2006a) Synaptic release of zinc from brain slices: factors governing release, imaging, and accurate calculation of concentration. J Neurosci Methods 154:19-29.

Frederickson CJ, Giblin LJ, Krezel A, McAdoo DJ, Muelle RN, Zeng Y, Balaji RV, Masalha R, Thompson RB, Fierke CA, Sarvey JM, de Valdenebro M, Prough DS, Zornow MH (2006b) Concentrations of extracellular free zinc $(\mathrm{pZn})_{\mathrm{e}}$ in the central nervous system during simple anesthetization, ischemia, and reperfusion. Exp Neurol 198:285-293.

Frerking M, Ohliger-Frerking P (2002) AMPA receptors and kainate receptors encode different features of afferent activity. J Neurosci 22:7434-7443.

Frerking M, Schmitz D, Zhou Q, Johansen J, Nicoll RA (2001) Kainate receptors depress excitatory synaptic transmission at CA3 $\rightarrow$ CA1 synapses in the hippocampus via a direct presynaptic action. J Neurosci 21:2958-2966.

Fukushima T, Shingai R, Ogurusu T, Ichinose M (2003) Inhibition of willardiine-induced currents through rat GluR6/KA-2 kainate receptor channels by zinc and other divalent cations. Neurosci Lett 349:107-110. Henze DA, Wittner L, Buzsaki G (2002) Single granule cells reliably dis- 
charge targets in the hippocampal CA3 network in vivo. Nat Neurosci 5:790-795.

Hirzel K, Muller U, Latal AT, Hulsmann S, Grudzinska J, Seeliger MW, Betz H, Laube B (2006) Hyperekplexia phenotype of glycine receptor alpha1 subunit mutant mice identifies $\mathrm{Zn}\left({ }^{2+}\right)$ as an essential endogenous modulator of glycinergic neurotransmission. Neuron 52:679-690.

Hoo KH, Nutt SL, Fletcher EJ, Elliott CE, Korczak B, Deverill RM, Rampersad V, Fantaske RP, Kamboj RK (1994) Functional expression and pharmacological characterization of the human EAA4 (GluR6) glutamate receptor: a kainate selective channel subunit. Receptors Channels 2:327-337.

Howell GA, Welch MG, Frederickson CJ (1984) Stimulation-induced uptake and release of zinc in hippocampal slices. Nature 308:736-738.

Huettner JE (2003) Kainate receptors and synaptic transmission. Prog Neurobiol 70:387-407.

Izumi Y, Auberson YP, Zorumski CF (2006) Zinc modulates bidirectional hippocampal plasticity by effects on NMDA receptors. J Neurosci 26:7181-7188.

Jung MW, McNaughton BL (1993) Spatial selectivity of unit activity in the hippocampal granular layer. Hippocampus 3:165-182.

Kamboj SK, Swanson GT, Cull-Candy SG (1995) Intracellular spermine confers rectification on rat calcium-permeable AMPA and kainate receptors. J Physiol (Lond) 486:297-303.

Kamiya H, Ozawa S (2000) Kainate receptor-mediated presynaptic inhibition at the mouse hippocampal mossy fibre synapse. J Physiol (Lond) 523:653-665.

Kamiya H, Shinozaki H, Yamamoto C (1996) Activation of metabotropic glutamate receptor type $2 / 3$ suppresses transmission at rat hippocampal mossy fibre synapses. J Physiol (Lond) 493:447-455.

Kantheti P, Qiao X, Diaz ME, Peden AA, Meyer GE, Carskadon SL, Kapfhamer D, Sufalko D, Robinson MS, Noebels JL, Burmeister M (1998) Mutation in AP-3 delta in the mocha mouse links endosomal transport to storage deficiency in platelets, melanosomes, and synaptic vesicles. Neuron 21:111-122.

Kay AR (2003) Evidence for chelatable zinc in the extracellular space of the hippocampus, but little evidence for synaptic release of Zn. J Neurosci 23:6847-6855.

Laube B, Kuhse J, Rundström N, Kirsch J, Schmieden V, Betz H (1995) Modulation by zinc ions of native rat and recombinant human inhibitory glycine receptors. J Physiol (Lond) 483:613-619.

Lerma J (2003) Roles and rules of kainate receptors in synaptic transmission. Nat Rev Neurosci 4:481-495.

Li Y, Hough CJ, Frederickson CJ, Sarvey JM (2001a) Induction of mossy fiber $\rightarrow$ Ca3 long-term potentiation requires translocation of synaptically released $\mathrm{Zn}^{2+}$. J Neurosci 21:8015-8025.

Li Y, Hough CJ, Suh SW, Sarvey JM, Frederickson CJ (2001b) Rapid translocation of $\mathrm{Zn}^{2+}$ from presynaptic terminals into postsynaptic hippocampal neurons after physiological stimulation. J Neurophysiol 86:2597-2604.

Lin DD, Cohen AS, Coulter DA (2001) Zinc-induced augmentation of excitatory synaptic currents and glutamate receptor responses in hippocampal CA3 neurons. J Neurophysiol 85:1185-1196.

Low CM, Zheng F, Lyuboslavsky P, Traynelis SF (2000) Molecular determinants of coordinated proton and zinc inhibition of $N$-methyl-D-aspartate NR1/NR2A receptors. Proc Natl Acad Sci USA 97:11062-11067.

Matias CM, Matos NC, Arif M, Dionisio JC, Quinta-Ferreira ME (2006) Effect of the zinc chelator $N, N, N^{\prime}, N^{\prime}$-tetrakis (2-pyridylmethyl)ethylenediamine (TPEN) on hippocampal mossy fiber calcium signals and on synaptic transmission. Biol Res 39:521-530.

Mayer ML, Vyklicky LJ, Westbrook GL (1989) Modulation of excitatory amino acid receptors by group IIB metal cations in cultured mouse hippocampal neurones. J Physiol (Lond) 415:329-350.

Molnar P, Nadler JV (2001) Synaptically-released zinc inhibits N-methyl$\mathrm{D}$-aspartate receptor activation at recurrent mossy fiber synapses. Brain Res 910:205-207.
Mott DD, Doherty JJ, Zhang S, Washburn MS, Fendley MJ, Lyuboslavsky P, Traynelis SF, Dingledine R (1998) Phenylethanolamines inhibit NMDA receptors by enhancing proton inhibition. Nat Neurosci 1:659-667.

Mott DD, Washburn MS, Zhang S, Dingledine RJ (2003) Subunitdependent modulation of kainate receptors by extracellular protons and polyamines. J Neurosci 23:1179-1188.

Mulle C, Sailer A, Perez-Otano I, Dickinson-Anson H, Castillo PE, Bureau I, Maron C, Gage FH, Mann JR, Bettler B, Heinemann SF (1998) Altered synaptic physiology and reduced susceptibility to kainate-induced seizures in GluR6-deficient mice. Nature 392:601-605.

Mulle C, Sailer A, Swanson GT, Brana C, O'Gorman S, Bettler B, Heinemann SF (2000) Subunit composition of kainate receptors in hippocampal interneurons. Neuron 28:475-484.

Paoletti P, Ascher P, Neyton J (1997) High-affinity zinc inhibition of NMDA NR1-NR2A receptors. J Neurosci 17:5711-5725.

Patton C, Thompson S, Epel D (2004) Some precautions in using chelators to buffer metals in biological solutions. Cell Calcium 35:427-431.

Pemberton KE, Belcher SM, Ripellino JA, Howe JR (1998) High-affinity kainate-type ion channels in rat cerebellar granule cells. J Physiol (Lond) 510:401-420.

Quinta-Ferreira ME, Matias CM, Arif M, Dionisio JC (2004) Measurement of presynaptic zinc changes in hippocampal mossy fibers. Brain Res 1026:1-10.

Rose G, Diamond D, Lynch GS (1983) Dentate granule cells in the rat hippocampal formation have the behavioral characteristics of theta neurons. Brain Res 266:29-37.

Ruiz A, Walker MC, Fabian-Fine R, Kullmann DM (2004) Endogenous zinc inhibits $\mathrm{GABA}_{\mathrm{A}}$ receptors in a hippocampal pathway. J Neurophysiol 91:1091-1096.

Salin PA, Scanziani M, Malenka RC, Nicoll RA (1996) Distinct short-term plasticity at two excitatory synapses in the hippocampus. Proc Natl Acad Sci USA 93:13304-13309.

Schmitz D, Frerking M, Nicoll RA (2000) Synaptic activation of presynaptic kainate receptors on hippocampal mossy fiber synapses. Neuron 27:327-338.

Schmitz D, Mellor J, Nicoll RA (2001) Presynaptic kainate receptor mediation of frequency facilitation at hippocampal mossy fiber synapses. Science 291:1972-1976.

Seeburg PH (1993) The TiPS/Trends Neurosci lecture: the molecular biology of mammalian glutamate receptor channels. Trends Pharmacol Sci 14:297-303.

Smart TG, Xie X, Krishek BJ (1994) Modulation of inhibitory and excitatory amino acid receptor ion channels by zinc. Progr Neurobiol 42:393-441.

Sudhof TC (1995) The synaptic vesicle cycle: a cascade of protein-protein interactions. Nature 375:645-653.

Thompson RB, Whetsell Jr WO, Maliwal BP, Fierke CA, Frederickson CJ (2000) Fluorescence microscopy of stimulated $\mathrm{Zn}$ (II) release from organotypic cultures of mammalian hippocampus using a carbonic anhydrase-based biosensor system. J Neurosci Methods 96:35-45.

Traynelis SF, Burgess MF, Zheng F, Lyuboslavsky P, Powers JL (1998) Control of Voltage-Independent Zinc Inhibition of NMDA Receptors by the NR1 Subunit. J Neurosci 18:6163-6175.

Ueno S, Tsukamoto M, Hirano T, Kikuchi K, Yamada MK, Nishiyama N, Nagano T, Matsuki N, Ikegaya Y (2002) Mossy fiber $\mathrm{Zn}^{2+}$ spillover modulates heterosynaptic $\mathrm{N}$-methyl-D-aspartate receptor activity in hippocampal CA3 circuits. J Cell Biol 158:215-220.

Vignes M, Collingridge GL (1997) The synaptic activation of kainate receptors. Nature 388:179-182.

Vogt K, Mellor J, Tong G, Nicoll R (2000) The actions of synaptically released zinc at hippocampal mossy fiber synapses. Neuron 26:187-196.

Zheng F, Gingrich MB, Traynelis SF, Conn PJ (1998) Tyrosine kinase potentiates NMDA receptor currents by reducing tonic zinc inhibition. Nat Neurosci 1:185-191. 